\title{
EL EMBAJADOR ALFONSO DE LA SERNA, ESCRITOR Y PROMOTOR DE ESTUDIOS SOBRE LOS MORISCOS EN EL MAGREB
}

Mikel de Epalza*

\section{Presentación y hOMENAJE A Alfonso de la SERnA}

Este artículo quiere ser, en primer lugar, un homenaje a una persona a quien he apreciado mucho ${ }^{1}$, por su admirable y admirada labor de política cultural en un país árabe, Túnez [Tunicia, República Tunecina] $]^{2}$, donde tuve el honor y el placer de colaborar con él. Analizaré algo de su forma de trabajar en ese campo cultural.

* Universidad de Alicante.

1. Estas páginas forman parte de un estudio mío más amplio, que se publicó con título semejante pero de forma más breve y con otro enfoque, como diplomático que fue su protagonista: $\mathrm{M}$. DE EPALZA, «Breve estudio sobre el Embajador Alfonso de la Serna, escritor y promotor de estudios hispano-árabes en el Mágreb (Túnez y Marruecos, moriscos y el Estrecho)», en la revista del Ministerio de Asuntos Exteriores Awrâq. Estudio sobre el mundo árabe e islámico contemporáneo (Madrid), vol. XXIII (2006), pp. 201-217, estudio que dedico también a la familia De la Serna - Inciarte, como modesto homenaje a D. Alfonso.

2. El nombre tradicional del país es Túnez, en español, igual que el de su capital, la ciudad de Túnez, lo cual plantea un pequeño problema en nuestros días, ya que ambos referentes han entrado con más frecuencia en nuestro uso en los media y en la conversación, no como cuando era un país lejano y poco conocido. Se presta especialmente a equívocos cuando ambas realidades forman parte principal de un escrito, de un libro o un artículo, como en el presente trabajo. Los francófonos han hecho derivar el topónimo del país directamente del de la capital (Tunis, Tunisie), al igual que los italohablantes (Tunis, Tunisia) - por comparar con otras importantes lenguas románicas-. Pero en castellano ese procedimiento da un malsonante (Túnez,Tunecia), con deplorables derivados adjetivales tunecios y tunecias. Personalmente, preferiría tomar para el español (y para el catalán) el italiano Tunisia, como otros arabismos que han llegado por esa lengua hermana (mezquita, riesgo,...). Pero, por respetar mejor el origen etimológico tradicional adoptaría el doblete semántico Túnez/Tunicia. En el presente trabajo, hechas esas advertencias, usaremos para ambos lugares el tradicional topónimo único Túnez. Parecido problema se ha planteado con los nombres de Andalucía española (moderna) y andaluces, diferenciados de Al-Ándalus árabe (medieval) y andalusíes, como recoge el Diccionario de la Lengua Española de la Real Academia Española de la Lengua, Madrid, en su 21 a edición, 1992, tomo I, p. 137, y en otras ediciones anteriores y posteriores. Es un tema etimológico tratado a veces con el embajador De la Serna y su familia. 
Pero, además, haré una modesta reflexión de cómo él se encontró con un elemento de la política española en el mundo árabe contemporáneo, el "andalusismo" o estudio y recuerdo de Al-Ándalus, como territorio de entendimiento y de aprecio mutuo, entre árabes y españoles. Él lo fue descubriendo cada vez más, en sus 5 años de estancia y trabajo en Túnez. Y yo también empecé a apreciar el "andalusismo", que no me había llamado la atención en mis estudios universitarios anteriores, interesado como estaba por el diálogo inter-religioso islamo-cristiano. Algo se hablará, por tanto, de esa aproximación, intelectual y vital, al "andalusismo", como factor cultural y vital de acercamiento al pasado y al presente de la historia mediterránea de estos últimos 1.300 años.

\section{COLABORACIÓN PERSONAL CON LAS ACTIVIDADES CUlturales de Alfonso de la SERNA}

Mi personal relación con Alfonso de la Serna fue sobre todo profesional, la de un embajador de España y director general de Relaciones Culturales con un profesor de universidad e investigador en Estudios Árabes e Islámicos. Ha sido poco intensa, pero sí larga, de casi 40 años, desde 1968 a 2006.

Llegó él de Embajador a Túnez en abril de 1968. Yo estaba entonces de profesor en la Universidad de Lyon (Francia) y ese verano o el siguiente lo pasé en Túnez investigando sobre los moriscos en la documentación del consulado de Francia del siglo XVII ${ }^{3}$. Era una prolongación pendiente de mi tesis doctoral en Filología Semítica (Árabe), presentada en primavera de 1967 en la Universidad de Barcelona sobre otro tema hispano-árabe tunecino (también árabe-mallorquín, y de polémica islamo-cristiana), del siglo $\mathrm{XV}^{4}$. Pasé por la Embajada de España, donde trabajaban mis amigos, el matrimonio Infantes, a los que había conocido en Beirut. Así conocí y saludé a D. Alfonso de la Serna y hablamos desde entonces a menudo de sus curiosidades hispano-tunecinas, especialmente de los moriscos expulsados de España a principios del siglo XVII y de sus descendientes los andalusíes, con sus tradiciones de origen hispano, hasta nuestros días. Él me animó mucho a proseguir esas investigaciones, que iban a tener ya cierto eco internacional en el primer Coloquio Hispano-Tunecino de Hammamet (1969), propiciado por el propio embajador con las autoridades universitarias tunecinas, con encuentros regulares durante 20 años, alternativamente en Túnez y en España,

3. Véase publicación resultante, de M. DE EpALZA, «Moriscos y Andalusíes en Túnez en el siglo XVII», Al-Andalus (Madrid), XXXIV (1969), pp. 247-327, editado luego en francés, sin los apéndices documentales, en M. DE Epalza y R. Petrt (dirs.), Recueil d'études sur les Moriscos Andalous en Tunisie, Madrid, 1973, pp. 150-186.

4. M. DE EPAlza, Fray Anselm Turmeda ('Abdallâh al-Taryumân) y su polémica islamo-cristiana. Edición, traducción y estudio de la Tuhfa (con nueva presentación y prólogo de María Jesús Rubiera Mata), Madrid, 1994, $2^{a}$ ed.; $1^{\text {a }}$ ed., Roma, 1971). 
hasta $1989^{5}$. En semejante línea científica hispano-árabe se realizaría tres años después el importante primer encuentro de 1972 sobre moriscos, dirigido por el Profesor Galmés de Fuentes y su equipo de investigadores en la Universidad de Oviedo $^{6}$. Ambos congresos (el de 1969 y el de 1972) iban a contribuir a desencadenar en las décadas siguientes una serie de encuentros y de publicaciones, en diversas lenguas y países, sobre los temas moriscos, con una red internacional, cuyos principales centros estarían en España (Oviedo, Teruel, Alicante...), en Zaghouan y en Túnez (con Temimi, con Zbiss), en Francia (en Montpellier y París, con Cardaillac y Vincent), etc. Eran brotes diversos de semillas sembradas en gran parte por Alfonso de la Serna, desde su embajada de Túnez (1968-1973).

Al poco tiempo entró en la Embajada de España, como director del Centro Cultural Español, Ramón Petit, mi antiguo estudiante de Filología Semítica (Árabe) de la Universidad de Barcelona, y se iniciaron en la Universidad de Túnez los estudios de español con los profesores Limayem y Petit, estudios promovidos por el embajador de la Serna, mientras yo estaba estudiando en Damasco (1970-1971). El curso siguiente me añadí al grupo universitario tunecino, que seguiría y se ampliaría en una Licenciatura de Español, con las profesoras Mercè Riera y Josefina Veglison y sobre todo con el veterano profesor de español del Liceo de El Bardo José María Sastre y sus discípulos y discípulas, muchos de ellos ahora doctores formados en Francia y en España, hasta llegar a formar los más de cien profesores actuales de español en la enseñanza media, en todo el territorio de la República Tunecina ${ }^{7}$.

Mientras estaba yo aún en Siria fui invitado en 1971 por Alfonso de la Serna a dar una conferencia en Túnez sobre los moriscos y sus descendientes los andalusíes, instalados desde el siglo XVII en ese país. Fue un éxito de pú-

5. Véase más adelante, al presentar esos encuentros hispano-tunecinos promocionados inicialmente por Alfonso de la Serna, y especialmente el texto de M. DE EPALZA, «Recherches récentes sur les émigrations des "Moriscos" en Tunisie», Les Cahiers de Tunisie (Túnez), XVIII/6970 (1970), pp. 139-147.

6. Véase la publicación de Á. GALMÉs de FuENTES (dir.), Actas del Coloquio Internacional sobre Literatura Aljamiada y Morisca. Departamento de Filología Románica de la Facultad de Filosofía y Letras de la Universidad de Oviedo. 10 al 16 de julio de 1972, Madrid, 1978, donde publiqué ya un avance de presentación del mencionado libro DE EPALZA y PETIT, op. cit., en la ponencia de M. DE EPALZA, «Trabajos actuales sobre la comunidad de moriscos refugiados en Túnez, desde el siglo XVII a nuestros días», pp. 427-445 [texto luego publicado en Túnez en traducción francesa, en Les Cahiers de Tunisie (Universidad de Túnez), XVIII/ 69-70 (1970), pp. 139-147, y en reedición en español, en el volumen de S.-M. ZBISS, A.-H. GAFSI, M. BougHANMi y M. DE EpALZA (edits.), Etudes sur les Morisques Andalous, Túnez, 1983, pp. 229-241. Sobre ese grupo de investigadores ovetenses sobre moriscos y literatura aljamiado-morisca, véase el volumen especial publicado en Túnez, años más tarde, por A. Temimi (dir.), Hommage à l'Ecole d'Oviedo d'Etudes Aljamiado (dédié au Fondateur Álvaro Galmés de Fuentes), Zaghouan, 2003.

7. Información proporcionada por quien fuera estudiante del Liceo de El Bardo y de la Facultad de Letras y Ciencias Humanas de la Universidad de Túnez, becario en la Universidad Autónoma de Madrid, profesor de Liceo y, actualmente, Inspector General de los profesores de español en la enseñanza media tunecina, Sr. Hedi Oueslati. 
blico, por la acción de Ramón Petit a las órdenes del embajador, en una gran sala del centro de la ciudad. Yo, entusiasmado por mis descubrimientos documentales sobre esos moriscos o andalusíes y sus actividades comerciales y sociales en la sociedad tunecina del siglo XVII, di muchísimos detalles nuevos sobre ellos. Pero noté en seguida cierta frialdad del público, que no se debía ciertamente a que di la conferencia en francés. Luego me dijeron que no era ésa la clase de información histórica que esperaban los tunecinos sobre los inmigrantes andalusíes del pasado. Eran las "glorias de la civilización" del AlÂndalus árabe y de la España europea del Siglo de Oro, de los que se sentían herederos no sólo los descendientes de los moriscos sino toda la sociedad tunecina y la árabe e islámica en general, en el siglo XX. Aprendí la lección, cuando estaba yo entonces descubriendo en Oriente el "Andalusismo", esa fascinación bastante generalizada por Al-Ándalus transmitida a las nuevas generaciones de jóvenes árabes por los libros de texto de la enseñanza media siria". También Alfonso de la Serna estaba descubriendo en Túnez la "fascinación de Al-Ándalus", en las relaciones especiales entre los árabes y España, como él mismo lo mostraría a lo largo de todo su libro Imágenes de Túnez, especialmente con su narración de su conversación emblemática con el viejo prócer e historiador "andalusí" Hasan Husni Abdelwahab (y la conversación de éste con el rey de España Alfonso XIII, varias décadas antes), que son hechos nada anecdóticos y de los que se hablará algo más adelante.

De la conferencia "fallada" me resarcí en parte, dos años después, en Túnez, cuando di mi primera conferencia en público totalmente en árabe, con ocasión de un homenaje al escritor y periodista radiofónico exitoso Othman Kaak, divulgador de la historia de los moriscos o andalusíes tunecinos. Inicié mi parlamento excusándome por mi acento extranjero, pero afirmando que se trataba de la historia árabe de mi país y que "había preferido hablar el árabe con dificultad que el francés con facilidad, en esta ocasión tan notable". Había sugerido a Alfonso de la Serna que asistiera al acto de homenaje al "hispanista" Othman Kaak, con Ramón Petit. El embajador se hizo explicar el porqué del aplauso atronador de la sala a esas primeras palabras mías en árabe y meditó durante toda la sesión, porque al salir nos participó de sus reflexiones sobre la

8. Ver la publicación más sustanciosa de mis estudios en Siria, M. DE EPALZA, «España y su historia vista por los árabes actuales (A partir de los textos de enseñanza media de Siria)», $A l-$ menara (Madrid), 2 (1972), pp. 53-108, resumida más adelante en ID., «L'histoire d'Al-Andalus dans les livres de texte de l'enseignement secondaire», Actas del II Coloquio hispano-tunecino de historiadores, Madrid, 1973, pp. 117-129. Con otras clases de fuentes árabes, más elaboradas, véase P. Martínez Montávez, Al-Andalus, España, en la literatura árabe contemporánea. La casa del pasado, Madrid, 1992. El embajador de España y director general del Instituto HispanoÁrabe de Cultura, D. Teodoro Ruiz de Cuevas, viejo especialista en derecho árabe y en las sociedades marroquíes -así como lo había sido su padre, magistrado en Casablanca-, me comentaría, sobre aquel estudio de textos escolares árabes, algo así como: "Si supiéramos los diplomáticos españoles estas bazas culturales con las que contamos para tratar con los árabes...". Alfonso de la Serna sí que lo supo, en Túnez. 
importancia de una acción cultural en árabe y sobre la historia común que une a españoles y tunecinos.

Años después, también tuve ocasión de devolver a los sirios, en Damasco, algo de lo mucho que había aprendido allí. Ante la Ministra de Cultura y otras autoridades universitarias y culturales de ese país y tras una desacertada y machacona presentación de mi persona por parte de un libanés como "gran orientalista español" (al-mustáxriq al-kabir), agradecí en árabe la deferencia, pero protesté por el título de "orientalista", que sabía era muy despreciado políticamente en Oriente Medio árabe por sus connotaciones coloniales anti-árabes: "No estudio la historia y la civilización de Oriente, lejano de mi país, sino estudio una parte indisociable de la historia de mi propio país, como la historia y civilización de Al-Ándalus forma parte indisociable de la historia y de la civilización de los árabes. No soy un "orientalista, soy un andalusista" [inventándome el neologismo mustandálusi, en árabe]. Hubo aplauso cerrado de desagravio, por lo del libanés, y, el día siguiente, salió en titulares de la prensa siria, en letra gorda y entrecomillado, la noticia de la conferencia del "mustandálusi" español.

De ese lento descubrimiento de las dimensiones actuales y sociales de ese "andalusismo" tunecino ${ }^{9}$, unido a la erudición científica de los historiadores en varias ramas del saber, iba a salir, en 1973, nuestro libro Receuil d'études sur les Morisques Andalous en Tunisie, volumen que recogía en francés y presentaba 32 estudios de 28 autores, entre ellos los de H.H. Abdulwahab (1917), de J. Oliver Asín (1933) y de J.D. Latham (1957), que habían constituido también unos hitos fundamentales en el conocimiento de los moriscos y sus descendientes en Túnez. La iniciativa de Alfonso de la Serna, quien había propiciado mi estancia y trabajo en Túnez, y la edición del libro entre las publicaciones del Ministerio de Asuntos Exteriores español habían dado uno de sus primeros frutos, abriendo una nueva era en los estudios hispano-andalusíes, como iba a presentarlo el mismo D. Alfonso en su Imágenes de Túnez, del que se hablará también más adelante ${ }^{10}$. Aquel libro nuestro en francés iba a tener una segunda parte complementaria, con otro volumen que recogía igualmente 18 trabajos nuevos (en árabe, en español y en francés), iniciativa de las autoridades culturales tunecinas, en $1983^{11}$.

9. Expuesto, unos años después, en A. GAFSI-SLAMA, «Túnez y España en el siglo XVII a través de los "moriscos"», y M. DE EPALZA, «Los moriscos o andalusíes en la historia vivida por los tunecinos», en J. GIRAlt (dir.), Túnez. Tierra de culturas, Barcelona, 2003, pp. 139-144 y 145152, respectivamente [ediciones en español, en francés, en árabe y en inglés].

10. Véase A. DE LA SERNA, Imágenes de Túnez, Madrid, 1979, 1990 (2ª ed.), $3^{\text {a }}$ reimpresión (en preparación), especialmente los capítulos “Los Andaluces” (I y II), pp. 237-272, y también la presentación del libro de EPAlza y Petit, op. cit., pp. 247-248, en el libro de Alfonso de la Serna.

11. Véase ZBiss, GAFsi, Boughanmi y Epalza, op. cit. 


\section{CONTEXTO DE COOPERACIÓN DIPLOMÁTICA - UNIVERSITARIA ESPAÑOLAS}

Con Alfonso de la Serna aprendí modestamente, en la práctica de muchos años de colaboración, en Túnez y en Madrid, la forma de actuar y el provecho de una estrecha colaboración entre funcionarios y profesionales de nuestros dos Ministerios, de Asuntos Exteriores y de Educación y Ciencia, todo ello rodeado de un siempre creciente aprecio personal entre él y yo y de cierto sentido del humor en algunas discrepancias puntuales ${ }^{12}$. Fue una relación profesional no muy intensa, como ya he dicho -nos veíamos quizás una o dos veces al mes, cada uno metido en nuestro trabajo- pero larga en el tiempo -casi cuarenta años, hasta la correspondencia bastante seguida, estos últimos años, alrededor de los estudios sobre los moriscos expulsados de España a principios del siglo XVII y sus descendientes los andalusíes tunecinos y sobre el prólogo suyo, aún inédito, que le pedimos y que nos escribió D. Alfonso para un libro, que estamos a punto de terminar, el investigador tunecino y alto funcionario del Ministerio de Cultura Dr. Abdel-Hakim Gafsi Slama y yo ${ }^{13}$.

En realidad, su acción y ejemplo diplomáticos fueron una escuela modélica de trabajo para mí en el mundo árabe. Pero había sido precedido por mi trato con el embajador Los Arcos (Argel, 1965) ${ }^{14}$ y seguido por el trato con el em-

12. Recuerdo que cuando era yo profesor de la Universidad de Túnez, con contrato financiado por el Gobierno Español, me reprochaba a veces que en público utilizara mi nombre de pila en eusquera o vascuence (Mikel, como había sido bautizado y como figuraba inscrito en el consulado de España, en el exilio republicano francés de Pau, en 1938). Un día le contesté “¡Sr. Embajador! Considérelo un seudónimo literario. ¡Y déjeme en paz!". Se debió de acordar que él mismo era escritor galardonado, nieto de Concha Espina y pariente de tantos literatos, y no me habló más de ese tema... y yo dejé que me pusiera Miguel en la autoría del libro sobre los moriscos en Túnez que él me había encargado y que había hecho publicar en el Ministerio de Asuntos Exteriores, en 1973. O recuerdo también, con los años transcurridos, que le entregaba la lista de mis amigos de la Universidad de Túnez, que me había pedido diplomáticamente para la recepción oficial de la Embajada, del 18 de julio, y hablábamos luego con entusiasmo de las novedades científicas sobre los moriscos en Túnez que iba yo a presentar en un congreso científico en Oviedo... a mediados de julio. Con lo que su "treta" para hacerme asistir a esa recepción del 18 de julio, como a los demás funcionarios dependientes de la Embajada, resultaba perfectamente inútil.

13. M. De EPAlza y A. GAFSI Slama, El español hablado en Túnez por los moriscos y sus descendientes (siglos XVII-XVIII). Material léxico y onomástico documentado (ss. XVII-XX) [volumen de unas 800 páginas, a punto de terminarse, en 2007]. Ver ya presentación de este trabajo por sus dos autores en «Lengua y onomástica hispánicos de los moriscos, conservados en Tunicia», VII Simposio Internacional de Mudejarismo (Teruel. 19-21 de septiembre de 1996), Teruel, 1999, pp. 633-641.

14. Primer embajador de España en la recién independizada Argelia y amigo personal de parte de mi familia navarra (Aranzadi, Epalza, Irujo, Ruiz de Alda...), me explicaba -cuando yo estaba en Argelia preparando mi tesis doctoral, en 1965- las situaciones excepcionales que le tocaba vivir, en un país que tenía que transformar cuatro provincias o "departamentos" franceses en un importante Estado moderno, a menos de $200 \mathrm{~km}$ al sur de España, "límite meridional, mediante el mar", en expresión notarial tradicional en Alicante, en catalán-valenciano, como aprendí más tarde. 
bajador Aguirre de Cárcer (Damasco, 1970-1971), que me marcaron profesionalmente, aunque seguramente no tanto como lo hizo Alfonso de la Serna. También pude constatar, ya de vuelta a España en Madrid, la importancia del Instituto Hispano-Árabe de Cultura, del Ministerio de Asuntos Exteriores, y de sus actividades, para la promoción de las relaciones culturales hispano-árabes y especialmente para las actividades universitarias, en España y en esos países (becas, viajes, congresos, bibliotecas, conferencias, investigaciones, publicaciones varias, etc.).

\section{ACCIÓN EN EL ÁMBITO DE LA RESTAURACIÓN ARQUEOLÓGICA Y DE LOS CENTROS CULTURALES}

No se ha podido recoger aún toda la producción literaria escrita de Alfonso de la Serna, sobre todo en la prensa madrileña, donde ya en 1962 él había ganado el Premio de Periodismo "Mariano de Cavia", del diario $\mathrm{ABC}^{15}$. En este diario madrileño y en el Informaciones de su familia ha publicado artículos de actualidad, durante medio siglo. Reeditó recientemente en un libro una selección de sólo 26 artículos de ABC, sobre seis zonas geopolíticas (Portugal, Francia, Inglaterra, Hispano-américa, Filipinas y el Norte de África), con 5 de ellos que se dedican a "El lejano Mágreb de ahí enfrente" ${ }^{16}$, con unas líneas de "Explicación previa al lector". Allí expresaba lo más medular de su pensamiento geopolítico sobre esa región del Mediterráneo, tan cercana e importante para España: “Y El Mágreb, a ocho millas al sur de Tarifa, en donde comienza, para nosotros, nada menos que África, el Islam, y el mundo árabe: tres magnas realidades de la geografía y la historia, a las que se diría que miramos como si se hallasen a una enorme distancia, sobre todo Marruecos, desde cuyas costas empezó a llegarnos el impulso histórico que cristalizó un día en la espléndida realidad de Al-Ándalus, Marruecos, al que tantos españoles contemplan como si estuviera en la sombra, habitada por sombras..."17.

Menos aún se ha hecho un esbozo de estudio sobre su labor cultural, cuyas grandes líneas apenas se podrán señalar en el apresurado volumen de

15. A. DE LA SERNA, «El arca de alcanfor», $A B C$ (Madrid), 11 de julio de 1962, reproducido en el capítulo "Filipinas de los abuelos", en ID., Las Fronteras Sensibles de España. Memoria fiel de nuestros vecinos históricos, Burgos, 2004, pp. 163-165, artículo periodístico del que escribió, en la reedición, "Tuve, encima, una íntima satisfacción: el artículo iba dedicado a Filipinas; y mi madre nació en Manila y tres generaciones de su española familia nacieron, vivieron o murieron en las Islas Filipinas", ibídem, p. 5.

16. Con los significativos títulos de "Marruecos", "La sombra del Islam", "El lejano Magrib de ahí enfrente", "Cervantes en la Goleta" y "Bertuchi, pintor de Marruecos", en A. DE LA SERNA, Las Fronteras..., pp. 55-86.

17. A. DE LA SERnA, Las Fronteras..., p. 12. 
Awrâ $q^{18}$. El mismo Alfonso de la Serna me comentaba un día lo difícil que iba a ser, para los historiadores futuros, documentar la acción diplomática en nuestra época, en la era del teléfono, de los telegramas y de los fax, y no digamos del correo electrónico, que dejan prácticamente muy pocas huellas documentales. Por eso también los testimonios que quedan en la memoria de los que le hemos conocido y que pudimos registrar esos testimonios por escrito en las páginas de estos artículos de homenaje adquieren un valor especial, por muy parciales y sintéticos o globales que sean.

En el capítulo de Rodolfo Gil en el mencionado volumen XXIII (2006) de la revista Awrâq (Madrid), en homenaje a Alfonso de la Serna, se puede ya advertir con interés las páginas que ese arabista, historiador y etnólogo, dedica a la acción diplomática de Alfonso de la Serna, especialmente en lo que se refiere a la renovación y aplicación, punto por punto, de los acuerdos culturales hispano-árabes del gobierno español con las autoridades culturales tunecinas, marroquíes y de otros países árabes, desde sus cargos de director general de Relaciones Culturales, en Madrid (1963-1968 y 1976-1977), y de embajador de España en algunos países árabes, Túnez (1968-1973) y Marruecos (1977-1983). En ese mismo capítulo, se señala muy oportunamente la labor de los Centros Culturales en países árabes (ahora Centros Cervantes, en el mundo entero), que Alfonso de la Serna tuvo bajo su responsabilidad, y la importancia que él les dio merecidamente y que actualmente siguen teniendo para las relaciones hispano-árabes y para miles de ciudadanas y ciudadanos de esos países. También subraya Rodolfo Gil cómo, en el caso tunecino, procuró que España financiara -en proyectos bilaterales o multilaterales internacionales- la restauración de algunos monumentos de Túnez particularmente significativos en las relaciones culturales entre los dos países: la restauración del mausoleo del escritor mallorquín (bilingüe, en catalán y en árabe) Abdallah At-Taryumán / Anselm o En Telm Turmeda (siglo XIV-XV), en el barrio de Bab-El-Menara ${ }^{19}$; la restauración también de la preciosa záwiya o mausoleo-mezquita de Sidi Az-Zaliyi ("El Azulejero"), patrón del gremio de los artesanos constructores, monumento que albergó en un primer momento a los moriscos o andalusíes expulsados de España y acogidos en Túnez (siglo XVII) ${ }^{20}$ y -ya por la acción política de otros embajadores españoles sucesores suyos- también la restauración del

18. Véase especialmente, con detenimiento, las páginas de R. GIL BENUMEYA GRIMAU, «Alfonso de la Serna, creador minucioso de buenas relaciones», en el volumen de homenaje de la revista Awrâq (Madrid), XXIII (2006), pp. 183-187.

19. Reproducido en un viejo dibujo de mediados del siglo XX, en la portada de M. DE EpALZA, Fray Anselm Turmeda...

20. Véase el capítulo «La Zauiya de Sidi Qasim en Túnez», del libro de A. Almagro GorbeA, Tres monumentos islámicos restaurados por España en el Mundo Árabe, Madrid, 1981, pp. 91-131, sobre la restauración del monumento, para transformarlo en el Museo Epigráfico de Túnez, con decenas de inscripciones artísticas de la capital, especialmente funerarias. 
fortín español en el islote Chikli, a pocos metros de la costa norte de la capital, en la gran laguna o Albufera (al-buhayra) que separa el puerto de Túnez del costero de La Goleta ${ }^{21}$. En esa misma línea, la administración tunecina piensa restaurar el viejo edificio del Consulado de España -desde finales del XVIII ${ }^{22}$, en la zona portuaria de los consulados y de población extranjera de la vieja Medina de la capital, entre Bab al-bahr ("Puerta del Mar") y Bab al-yazîra ("Puerta de la Península" del Cap Bon, al sur de la vieja ciudad) ${ }^{23}$.

\section{FORMAS DE ACERCAMIENTO A LAS REALIDADES CULTURALES TUNECINAS. TEXTOS}

Además de acercarse a los lugares y monumentos u objetos materiales del pasado, Alfonso de la Serna se acercaba a las personas. Creo que su procedimiento de penetrar en la realidad hispano-tunecina queda bien reflejado en dos episodios, representados en sus escritos: su iniciativa de hermanar la ciudad de Túnez con la de Barcelona ${ }^{24}$ y su visita al ya muy anciano historiador tunecino Hasan Husni Abdulwahab, alto funcionario y ex-ministro, a las pocas semanas de su toma de posesión como embajador de España en Túnez. El primer episodio figura en su primer y más importante libro sobre Túnez y el segundo está reflejado en varios escritos sobre su experiencia tunecina, aunque vamos a reproducir aquí el último que escribió, pocos meses antes de su fallecimiento, texto aún inédito en su totalidad, pero recientemente adelantado también en otro homenaje a Alfonso de la Serna:

“Una de las plazas más grandes, si no la mayor, de la moderna ciudad de Túnez es la llamada de Barcelona, que tuve el honor de inaugurar hace años como un hito de los actos de hermanamiento entre las dos capitales, la tunecina y la catalana. En medio de unos jardines y fuentes hay un relieve escultórico

21. Véase A. GARín (coord.), Santiago de Chikli. Una fortaleza española en Túnez, Madrid, 2003, presentado en una reseña del volumen precedente de esa misma revista por A. GAFSI SLAMA, Awrâq (Madrid), XXII (2001-2005), pp. 507-508.

22. Ver orígenes y evolución de esa sede diplomática, en J. PRADELLS NADAL, Diplomacia y comercio. La expansión consular española en el siglo XVIII, Alicante, 1992; M. DE EPALZA, «Intereses árabes e intereses españoles en las paces hispano-musulmanas del XVIII», Anales de Historia Contemporánea (Murcia - Orihuela), 1 (1982), pp. 7-17 [versión francesa, en Studia Islamica (París), LVII (1983), pp. 147-181], y M. DE EPALZA y A. GAFSI SLAMA, «Relations tuniso-espagnoles au XIXe siècle: documents et synthèse», Les Cahiers de Tunisie (Túnez), XXVI/101-102 (1978), pp. 185-216 [artículo ampliado y puesto al día, por los mismos autores y en español, en «Relaciones entre España y Túnez en el siglo XIX. Nueva documentación y síntesis», Anales de Historia Contemporánea (Murcia), XXIII (2007), pp. 259-276], y A. GAFSI SLAMA y M. DE EPALZA, «Texto sobre la llegada del cónsul general Francisco Seguí a la Regencia de Túnez (1804) y su correspondencia diplomática», Awrâq (Madrid), XXII (2002-2005), pp. 171-182.

23. Información que agradezco al Dr. Abdel-Hakim Gafsi Slama.

24. A. DE LA SERnA, Imágenes de Túnez..., $2^{a}$ ed., p. 298. 
donado por el municipio de Barcelona, que representa una sardana bailada por un grupo de árabes y catalanes. Están los danzantes dándose las manos, haciendo la rueda de la vieja danza de la Cerdaña, el círculo de la amistad. Pensé, al ver la escena petrificada, por la primera vez, que era un símbolo certero. Por encima de los enfrentamientos y las guerras, por encima de la sangre y el dolor, los dos viejos reinos mediterráneos se habían conocido y ahora giraban, de costa a costa, la rueda de la amistad; una rueda que empezó a rodar hace siglos cuando catalanes inquietos se lanzaron a la mar al grito de ¡Aragó! ¡Aragó!"”25.

La segunda anécdota es de las primeras semanas de la estancia del embajador Alfonso de la Serna en Túnez, en otoño de 1968. Fue un encuentro fundamental con Hasan Husni Abdulwahab, aunque el nonagenario tunecino falleció al poco tiempo, un encuentro decisivo para su visión y su actuar en el país. La ha contado muchas veces ${ }^{26}$. La última fue pocos meses antes del propio fallecimiento del embajador Alfonso de la Serna, en el prólogo que le pedimos a un libro en prensa, aún inédito. Es la versión que reproducimos a continuación.

"Estamos ante un tema, no ya sugestivo sino fascinante, según mi parecer: ¡los moriscos! [...]

El presente prólogo que sea, al menos, para justificar mi entusiasmo por el asunto y contribuir de esa manera a poner al lector en el estado de ánimo que merece el texto que aquí se abre. Lo haré sin dar lecciones de nada sino exhumando algunos recuerdos y sentimientos personales que quizás puedan empezar a probar lo muy vivo que se encuentra el tema aquí tratado, lo entrañablemente que se halla unido a la historia de España, y a la de Túnez, y lo sorprendente que resulta para quien no haya sentido previamente la curiosidad hacia un episodio histórico que los maestros en la materia conocen bien y del que incluso existe una bibliografía, antigua y moderna, muy abundante.

En la primavera de 1968 llegué a Túnez, investido de la misión diplomática que, como embajador, se me había confiado. Iba provisto, en cuanto a los moriscos se refería, solamente de alguna pasada lectura -en primerísimo lugar, el libro de Julio Caro Baroja, Los moriscos del Reino de Granada, Instituto de Estudios Políticos, Madrid

25. A. DE LA SERNA, op. cit., p. 298, al final del penúltimo capítulo XVII “¡Aragó! ¡Aragó!”, al que añadió el epílogo en la segunda edición, en el capítulo XVIII “Túnez de Bourguiba", tras la destitución constitucional del presidente y fundador de la República Tunecina (pp. 299-331): “Y hoy, de Bourguiba, vivo pero silencioso, alejado, 'estatua de sí mismo' como yo le llamaba en 1979, en el último capítulo de este libro, se podría decir, parafraseando palabras célebres del general Mac Arthur, que 'los viejos generales nunca mueren, solamente se desvanecen...'” [p. 331, final del libro, en 1990].

26. Al menos, que recuerde, en el capítulo de A. DE LA SERNA, «La Tunisie et l’Espagne à l'heure actuelle», en EPALZA y PETIT, op. cit., pp. 378-382 (en pp. 379-380) [capítulo significativamente dedicado "A la mémoire de Sidi Hassen Hosni Abdulwahab"], en su libro Imágenes de Túnez, pp. 249, 259-260, y finalmente en 2005, en el "Prólogo" DE EPALZA y GAFSI-SLAMA, El español hablado..., aún inédito, páginas adelantadas como primicia en M. DE EPALZA, «El embajador Alfonso de la Serna...», pp. 210-214, y en el presente artículo. También sospecho que es de él la mención de ese encuentro histórico, de 1927, mencionado en el librito de autor anónimo titulado Histoire des relations tuniso-espagnole, Túnez, 1968 [presentado en nota a continuación]. 
1957-, de los primeros 'descubrimientos' y consejos que me prodigó todavía en España mi gran amigo el ilustre profesor y académico Jaime Oliver Asín -sobrino y discípulo del sabio maestro arabista don Miguel Asín Palacios-, y de los resúmenes históricos, culturales o etnográficos de algunas buenas y fiables guías de viaje que consulté. Eso era todo.

Pero pronto iban a comenzar, no ya la extensión de mis lecturas sobre el tema, sino también mis vivencias personales, humanas, en contacto directo con tunecinos que iban convirtiéndose en amigos míos y que guardaban con orgullo y conocimiento la memoria de sus antepasados moriscos venidos de España. Ahí llegó para mí lo que fue casi una revelación.

Empecé por el principio. A muy pocos kilómetros de donde yo vivía, que era la costa que se extiende desde la propia ciudad de Túnez a los arenales de Rauad, se hallaba Cartago, hoy una villa moderna y residencial pero construida sobre las ruinas de la Cartago romana y los escasos vestigios que quedan de la Cartago púnica. Miles de años de historia se agolpaban allí. Pues bien, en un rincón de esa Cartago actual y al lado de lo que resta de los 'puertos púnicos' famosos, en donde un día remoto ancló la flota de Aníbal, había un pequeño grupo de residencias particulares. El lugar se llamaba Salam-bo, como la célebre novela histórica -Salambó- de Gustave Flaubert. En una de aquellas casas habitaba Si Hasan Husni Abdulwahab, a quien yo tenía el propósito de visitar cuando todavía estaba preparando en España mi viaje a Túnez. Así me lo había aconsejado Jaime Oliver Asín.

Abdulwahab era un venerable personaje de la cultura y la política tunecinas. Sabio erudito, bibliófilo eminente, antiguo ministro del gobierno beilical, Premio Nacional de Literatura, miembro de diversas academias, entre ellas la Real Academia Española de la Historia, viejo amigo de don Miguel Asín Palacios, Hasan Husni Abdulwahab era ya, a sus noventa años, una leyenda viva de la cultura tunecina de su tiempo. Conocerle era para mí una introducción indispensable hacia aquel tema histórico que estaba intrigándome desde antes de llegar a tierras tunecinas. Así que al poco de instalarme en Túnez y habiendo cumplido los primeros y urgentes deberes de mi misión, solicité visitarle. Pero su frágil salud le impidió recibirme entonces y tuve que esperar al 17 de septiembre, fecha en que por fin crucé el umbral de su casa en aquel evocador lugar de Salam-bo. Fue ésta mi primera y última visita al sabio insigne. Pocas semanas después, fallecía. He narrado esta visita en el capítulo que escribí para el libro mencionado más arriba, por lo que no voy a repetir el relato de un encuentro para mí inolvidable y del que guardo no sólo el recuerdo vivo en mi memoria sino un obsequio precioso que me hizo Abdulwahab, consistente en un pergamino de una página de separación y adorno de un Corán escrito en Córdoba en el siglo IX [...]. Así 'vivían' en él los testimonios más lejanos de un pasado común.

Hasan Husni Abdulwahab fue algo así como el patriarca de la historiografía tunecina del siglo XX acerca de la aportación étnica extranjera en su país. Escribió un trabajo que tuvo un éxito resonante y que se titulaba Coup d'oeuil général sur les apports ethniques étrangers en Tunisie. En él se dedicaban interesantísimas páginas a los que en Túnez llaman aún 'Andalous' y nosotros decimos 'moriscos' o hispanoárabes. Yo creo que del estímulo de ese trabajo arrancan muchas de las obras que posteriormente se fueron dedicando a este subyugante tema. Mi anfitrión y yo hablamos de mil cosas, o, más bien, yo no hacía más que escucharle, aprendiendo las mil cosas que él me fue enseñando. Al final de la conversa- 
ción Abdulwahab me contó -y aquí termino la anécdota de mi visita- que, hacía muchos años, él había tenido en Bizerta la ocasión de conocer personalmente al Rey Don Alfonso XIII de España, a quien en conversación amistosa había dicho, con cierto humor, que él consideraba poseer ciertos derechos históricos y sentimentales sobre Almería, pues sus antepasados habían reinado en aquella ciudad andaluza -supongo yo que en tiempos de los reinos de 'taifas'-. Don Alfonso le respondió, con no menos humor y gentileza, que si Hasan Husni regresaba a España él le entregaría las llaves de la ciudad ${ }^{27}$. Tan vivos eran los recuerdos y la conciencia de un pasado histórico lejano, que en pleno siglo XX era posible una conversación semejante entre dos hombres que yo he podido aún llegar a conocer $^{28}$. Esa conciencia la he visto palpitar en personas, hogares familiares, poblaciones, topónimos, apellidos, palabras del lenguaje cotidiano, artes, artesanías, estudios, monumentos, libros, durante los años de mi vida en Túnez.

Y fue a partir de aquel encuentro de septiembre de 1968 cuando empecé a tomar contacto vivo con el hecho históricos de los 'andaluces' -fueran moriscos de la gran emigración del siglo XVII, o hispanoárabes de más antiguos grupos tribales o familiares que llegaron a Túnez en siglos precedentes como había venido, por ejemplo, la familia del gran Ibn Jaldún o Abenjaldún, acontecimiento prolongado a lo largo de los tiempos, que 'tiñó' de cierto 'hispanismo', por así llamarlo, la sociedad del Reino y después Regencia de Túnez.

En aquel encuentro mío con la realidad cultural y humana de lo 'andaluz-morisco' fue decisiva para mi ilustración en el tema la presencia temporal en Túnez o los frecuentes viajes que hizo a ese país durante mi estancia el profesor Miguel de Epalza, de quien tanto he aprendido. Él sí era un auténtico experto en la materia y

27. Anotación complementaria mía al recuerdo de D. Alfonso: tres años antes, Hasan Husni Abdelwahab me había contado esa misma anécdota, sucedida en el brindis final del banquete que el entonces Ministro de Educación del Bey de Túnez, bajo "Protectorado" francés, había ofrecido al monarca español en el puerto de Bizerta, en una visita privada de Alfonso XIII en su yate "Giralda". Había una ligera variante: Abdulwahab había dicho que tenía la llave de la ciudad de Almería, heredada de sus antepasados. Alfonso XIII le había contestado sonriente "Excelencia, venga con su llave, que nosotros le haremos la puerta", lo cual corresponde más al conocido sentido del humor del monarca, en gran parte heredado por su nieto y sucesor pero con menos impertinencia, como la evitaba también el embajador de la Serna, en su amable eufemismo. ¡Ay esas llaves de emigrantes expulsos o sus descendientes, que no hay que cometer la zafiedad de pedir que te la enseñen materialmente, porque están en lo más íntimo de su corazón!

28. Este encuentro se habría celebrado el 10 de noviembre de 1927, según se lee en el librito Histoire des relations tuniso-espagnoles, Túnez, 1968, p. 52: “ROIS D'ESPAGNE A TUNIS [...] En 1927, le 10 novembre exactement, un autre roi d'Espagne visitait la Tunisie. Alphonse XIII débarquait en effet à Bizerte du cuirrassé «Prince Alphonse» et passait dans ce port une journée marquée notamment par la promenade qu'il tint à effectuer dans le quartier des Andalous". Sospechamos que esta pequeña publicación, de divulgación y de autor anónimo, había sido redactada o al menos programada, preparada y promovida por el recién llegado a Túnez embajador de España Alfonso de la Serna, con datos y textos recogidos previamente en España, como informa él mismo en el texto que nos entregó en 2005. Hay algunos detalles de fechas que faltan por aclarar, pero otros muchos datos confirmarían nuestra hipótesis. Sólo su posición de diplomático recién llegado explicarían su modestia en no figurar como autor de esta publicación, útil y emblemática de la acción cultural que él realizaría en el país, en los años siguientes, apoyado en la historia de las relaciones entre Túnez y España. 
fue haciéndose aún mucho más conforme profundizaba sus estudios y vivencias personales. A través de él, o ya de manera directa por mi lado - pues mi entusiasmo por el asunto iba siendo conocido de numerosos amigos tunecinos- fui materializando mi curiosidad por conocimientos más concretos. Leí los trabajos del profesor Epalza o los de autores que él me recomendaba. Conocí singulares personalidades tunecinas que me ilustraban en la materia. Uno de esos amigos fue el querido, sabio y entrañable Mustafá Slimane Zbiss, a cuya memoria se rinde homenaje en este libro $^{29}$. Viajé por el país, visitando villas y aldeas que habían sido lugares preferidos para el establecimiento de aquellos emigrados de España. Recorrí los zocos urbanos en donde aún se encontraban comerciantes o artesanos, herederos de los que con su mismo oficio, habían venido de ciudades y aldeas del antiguo 'Andalus'. Compartí 'cenas de Ramadán' con mis nuevos amigos y degusté los platos de la cocina tunecina que aún traían nombres y recetas llegadas hacía siglos de mi propio país.

Todo esto no era mera 'curiosidad arqueológica', ni conocimiento erudito y libresco, ni simple hallazgo casual de viajero fugaz. Era vivencia palpitante en el seno de un mundo dotado de memoria fiel. He tratado de explicarlo en dos capítulos titulados Los Andaluces, en el que doy cuenta de mis descubrimientos, aprendizajes y emociones" ${ }^{30}$.

\section{PUBLICACIONES SUYAS, PERSONALES Y FOMENTADAS}

Dentro de los límites temáticos de esta revista especializada Sharq AlÁndalus. Estudios Mudéjares y Moriscos, vamos a presentar los libros y otras publicaciones más breves (prólogos y capítulos de libros de otros, artículos de prensa, especialmente en los diarios madrileños $A B C$ e Informaciones), que escribió y que promocionó el embajador de España Alfonso de la Serna, especialmente sobre los moriscos y sus descendientes en Marruecos y Túnez.

“Durante cerca de seis años, como Embajador de España en Marruecos (1977-1983), he estado observando estos azares que hacían tan problemático el salto sobre fosos y muros aislantes (Tiempo atrás, había cumplido, a lo largo de cinco años, similar misión diplomática en Túnez, con lo que, en un total de casi once años, he podido vivir intensamente la paradoja de nuestros desconocimientos recíprocos, pese a la proximidad de eso que un día llamé ‘el lejano Mágreb de ahí enfrente').

No he podido librarme de meditar casi constantemente, mientras vivía mi experiencia Magrebí, acerca de esas barreras que tanto estorbaban nuestro mutuo y claro entendimiento. Como era natural, fue en Marruecos en donde

29. Nota añadida en este trabajo por M. de Epalza. Véase más adelante el párrafo de la colaboración del embajador de España Alfonso de la Serna con este escritor, historiador, hispanista, arqueólogo, restaurador y alto funcionario del Ministerio de Cultura tunecino.

30. Véanse esos dos densos y preciosos capítulos de A. DE LA SERNA, Imágenes de Túnez..., edic. 1990, capítulos XIV y XV, y «Los Andaluces», pp. 239-260 y 261-272. 
mis preguntas y reflexiones se transformaron en la imperiosa necesidad de encontrar alguna explicación a todo ello. Me propuse entonces ver qué había sucedido al sur de Tarifa, al otro lado del foso múltiple que nos separaba a fin de, si lograba comprender algo, poder contribuir a que, de nuestro lado, en España, se pudiera también algo entender. He aquí la razón del presente libro" ${ }^{31}$.

Sólo estas páginas de la "Explicación previa al lector" del libro de 2001, con más de 30 años de reflexión previa, señalan una importante inflexión en el pensamiento de Alfonso de la Serna. En Imágenes de Túnez dominaba el optimismo de la experiencia tunecina, lleno de ilusión ante las realidades y las posibilidades que ofrecía la situación social en ese país con respecto a España, con dos elementos fundamentales, la lejanía geográfica y la importancia del elemento cultural. En cambio, en lo referente a Marruecos, lo que más parece haber impresionado al embajador de España, ya en 1977, fueron dos situaciones conflictivas: la realidad de una vecindad "a ambos lados del estrecho", vecindad creadora de problemas socio-culturales, y el peso histórico de una serie de conflictos de toda clase.

Resumiendo quizá demasiado, la acción cultural de Alfonso de la Serna, en sus escritos, se centraron en Túnez en sacar a relucir los elementos positivos de las relaciones hispano-tunecinas, especialmente las culturales, pero también otras acciones de cooperación, poco conflictivas (ayuda en catástrofes naturales, promoción de industria pesquera tunecina, participación española en festivales musicales, etc.). En cambio, en Marruecos, el embajador de España empleaba seguramente gran parte de su actividad en solventar conflictos, muchos de ellos "de larga duración", "un malentendido histórico", como rezaba el subtítulo de su libro $\mathrm{Al}$ sur de Tarifa... De ahí el tono aparentemente más dramático de sus escritos desde Marruecos y sobre Marruecos, aunque se advierte igualmente el mismo optimismo profundo y una confianza en el poder pedagógico de la palabra escrita y de las explicaciones razonadas sobre el origen de los conflictos, para superarlos.

Leyendo sus escritos magrebíes, vemos cómo supo sobreponerse a las diferentes situaciones, las que se encontró en Túnez y las que tuvo que afrontar en Marruecos, con un mismo valor y con idéntica profesionalidad ${ }^{32}$. Supo comprender el reto que suponía trabajar en Marruecos, con la amplitud de los problemas con los que siempre se ha enfrentado España con ese país. Pero no renunció a ampliar la acción cultural que había desarrollado desde la Dirección General de Relaciones Culturales y, específicamente como embajador en un país árabe y magrebí, en su estancia en Túnez. En Marruecos y sobre Marruecos siguió escribiendo, en el país y hasta después de su jubilación profesional,

31. A. DE LA SERnA, Al sur de Tarifa. Marruecos-España: un malentendido histórico, Madrid, 2001, pp. 9-10.

32. Véase las aportaciones detalladas y muy significativas en los respectivos capítulos del mencionado volumen de homenaje, especialmente en R. GIL BENUMEYA GRIMAU, «Alfonso de la Serna, creador...», op. cit., pp. 183-187, y J. OrTEGA SALINAS, «Alfonso de la Serna, hombre de letras y cultura y profesional destacado», ibídem, pp. 189-192. 
en España ${ }^{33}$. Pero el texto suyo y el libro más importante que promovió fueron, además, el prólogo que redactó y el libro para el que éste estaba destinado, del Dr. Rodolfo Gil Grimau ${ }^{34}$. Son textos que analizaremos un poco más, al final de este trabajo.

Esta pequeña reflexión comparativa, en la mitad de este modesto estudio mío sobre la acción diplomática de Alfonso de la Serna, en su dimensión cultural en el Mágreb árabe, puede permitir proseguir en profundidad la presentación de las actividades de nuestro protagonista, en sus periplos árabes, en Túnez y en Marruecos.

\section{TÚNEZ: LOS MORISCOS Y SUS DESCENDIENTES ANDALUSÍES, UN IMPORTANTE PUENTE CULTURAL}

Una vez me comentaba el embajador Alfonso de la Serna cómo deseaba poner una placa conmemorativa en los lugares de Túnez ligados históricamente con la historia de España, y yo le señalaba que lo mejor era, previamente, dejar constancia de esa relación de lugares históricos, en los libros, como en su precioso Imágenes de Túnez, guía practica y memoria histórica para viajar por esos sitios de encuentro entre tunecinos y españoles de otros tiempos, en la actual República Tunecina ${ }^{35}$.

Su punto de partida en ese libro era el estudio ya mencionado del erudito tunecino Hasan Husni Abdulwahab ${ }^{36}$, presentado en el Congreso de los Orientalistas de Argel, en 1908. Ese congreso, en plena era colonial y en la Argelia ocupada por los franceses, tenía que inspirar al escritor árabe un texto abierto a todas las culturas del Mediterráneo, que sería uno de los ideales fundamentales de su país a

33. Véase, en particular, A. DE LA SERNA, Al sur de Tarifa..., ID., Las Fronteras..., ID., «Marruecos: color y esencia», en F. Márquez Villanueva, A. Azoulay, A. de la Serna y J. Costa (apéndice), Tres visiones sobre Marruecos-España, Sevilla, 2003, pp. 35-42.

34. A. DE la Serna, "Prólogo", en R. Gil Grimau, Aproximación a una bibliografía española sobre el Norte de África 1850-1980, Madrid, 1982, pp. 9-12. "Préface" [versión francesa, en el mismo volumen, pp. 25-28].

35. A. DE LA SERNA, Imágenes de Túnez. El libro está significativamente dedicado "A mi amigo Habib", Habib Bourguiba hijo, entonces Ministro de Asuntos Exteriores, hijo del fundador y entonces presidente de la República Tunecina Habib Bourguiba, con una amistad personal indefectible con el matrimonio de la Serna, hasta nuestros días, que se manifiesta bien en las páginas necrológicas que el ex-ministro envió desde Túnez para el homenaje ya mencionado de la revista Awrâq: H. BourguiBA Jr., «Homenaje al amigo», pp. 231-233.

36. H.H. AвDulWAHAB, «Coup d'oeil général sur les apports ethniques étrangers en Tunisie», Revue Tunisienne (Túnez), 1917, pp. 305-316, 371-379; reproducido en su totalidad en Les Cahiers de Tunisie (Túnez), XVIII/60-70 (1970), pp. 149-169, y en folleto aparte, y también parcialmente -sólo lo referente a los moriscos o andalusíes-, con una presentación previa, en EPALZA y Petit, op. cit., pp. 16-20. 
lo largo del siglo XX. La llegada e instalación de los moriscos expulsados de España, los "andalusíes", no se presentan principalmente de forma reivindicativa, de protesta ante las tropelías de las que fueron víctimas los moriscos -aunque este elemento reivindicativo esté siempre presente, también en el brindis de Bizerta, de ahí la finta humorística de Alfonso XIII al ministro Abdelwahab-, sino como un lazo más, muy positivo, entre la cultura árabe-tunecina y el resto de las culturas del mundo y, en particular, con Europa Occidental y con España ${ }^{37}$. Era un buen punto de partida para la tarea cultural hispano-tunecina que se había propuesto el embajador de la Serna. También nos lo sugirió para iniciar la publicación de los estudios del libro que hicimos sobre moriscos y sus descendientes andalusíes en Túnez ${ }^{38}$. Y es una reflexión de política cultural que expresa al final de sus capítulos sobre los andalusíes, "Los andaluces": "Volcarse sobre las páginas de estos manuscritos es una manera conmovedora de reencontrar aquellos seres dolorosamente desarraigados de su patria, España, 'la península verdeante', como a veces la llaman en su melancolía, desde las costas africanas, y de redescubrir el mundo diverso, mestizo, lleno de continuas contradicciones, cruzamientos difíciles, esperanzas de unidad en lo variado, que siempre ha sido España" ${ }^{39}$.

Él no dejó nunca de recordar ese exilio morisco y sus huellas en nuestros días, muy emotivamente, para él y para los demás, como lo hace en su escrito Recuerdos vivos de moriscos españoles en el Mágreb, donde sintetiza lo que fue la expulsión de los moriscos, comparándola con los lloros del Cid Campeador en su camino del exilio de su patria castellana y recordando las múltiples huellas que él pudo contemplar en el Magreb árabe, tanto en Túnez y Marruecos como en otros países como Argelia, gracias a sus lecturas ${ }^{40}$.

En esa misma línea, Alfonso de la Serna promovió el estudio de los andalusíes tunecinos, tema positivo fundamental en la conciencia nacional tunecina en relación con España. Ya se ha expuesto su iniciativa de la conferencia de 1971 y su presencia en el homenaje a Othman Kaak ${ }^{41}$. Más importante

37. Véase M. DE EPALZA, «Los moriscos o andalusíes...».

38. Véase H.H. AbdulwaHAB, op. cit. En el mismo libro A. de la Serna iniciaba su capítulo con una dedicatoria significativa "(A la mémoire de Sidi Hassen Hosni Abdelwahab)", continuando su relación amistosa con su familia, su mujer -de origen turco y fuerte personalidad-y su hijo Jáled.

39. A. DE LA SERNA, Imágenes de Túnez..., pp. 271-272.

40. Artículo fotocopiado proporcionado a la revista Awrâq por la familia De la Serna (D. Fernando) y transmitido para este trabajo por el Dr. Fernando de Ágreda, secretario del Comité de Redacción de la revista y coordinador del volumen de homenaje. A todos ellos agradezco mucho la información sobre tan bello y significativo texto, evidentemente. Véase A. DE LA SERNA, «Los moriscos españoles. Recuerdos vivos de moriscos españoles en el Mágreb», Sociedad Geográfica Española (Madrid), 18 (2002), pp. 14-28.

41. Asistí, poco tiempo después, a una comida en su honor, en la embajada de España, y pude comprobar directamente con qué protocolo y conversación, sencillo y eficaz, trataba el embajador a esa categoría de huéspedes culturales, como vi tratar al profesor francés e investigador medievalista Charles-André Dufourcq y a otros muchos, especialmente a españoles. 
aún fue su apoyo al libro Recueil d'études sur les Moriscos Andalous en Tunisie, de $1973^{42}$, donde él mismo escribió uno de los capítulos finales con una certera y positiva visión de los lazos culturales entre Túnez y España ${ }^{43}$. No hizo él el prólogo o presentación del libro por no quitar protagonismo al Ministro ["Secretario de Estado"] de Cultura tunecino, el profesor Chedly Klibi, que concluía el volumen con un texto sobre las positivas relaciones históricas hispanotunecinas, que encontraba en el tema de los moriscos andalusíes quizás su elemento más emblemático ${ }^{44}$.

La aportación de Alfonso de la Serna a ese libro fue multiforme, aunque siempre discreta (íbamos Petit y yo en el mismo avión que él con el "manuscrito" y las ilustraciones del libro, para la imprenta de Madrid, y no nos pidió verlo, a pesar de su interés). Él nos pasó la traducción francesa del artículo fundamental en inglés del profesor de la Universidad de Edimburgo John Derek Latham, que se había hecho hacer para difundirlo así entre los tuneci$\operatorname{nos}^{45}$. Encontró también financiación para las traducciones, para las ilustraciones y para otras necesidades materiales del libro.

Los dos capítulos "Los Andaluces", en el libro de de la Serna Imágenes de Túnez, indican a las claras la importancia que el escritor y diplomático español daba al tema de esos "hispano-árabes" en la historia emblemática y común entre los dos países ${ }^{46}$. También iniciaría su actividad al frente de la embajada de Rabat con una curiosidad por saber la importancia de los emigrantes moriscos o andalusíes en Marruecos ${ }^{47}$. Pero allí tuvo que ampliar su interés y su estudio a otros temas afines y a otras épocas, por las innumerables huellas que quedan

42. M. DE Epalza y R. Petit (edits.), op. cit.

43. A. DE LA SERNA, «La Tunisie et l’Espagne à l'heure actuelle», en EPALZA y PETIT, op. cit., pp. 378-382.

44. Ch. KLIBI, «Allocution au I Colloque d'historiens tuniso-espagnol à Hammamet», en EPALZA y PETIT, op. cit., pp. 383-385. [2-6 de marzo de 1969], donde recordaba su visita oficial con el presidente de la República Tunecina Habib Bourguiba, también preparada por el embajador de la Serna, de mucho alcance político, pero también basada en una común historia y sus huellas culturales en España].

45. Artículo fundamental y publicado en inglés -y por ello casi desconocido por los tunecinos, aunque estuviera en la revista de la Facultad de Letras de Túnez-: J.D. LATHAM, «Towards a study of Andalusian Immigrations and its place in Tunisian History», Les Cahiers de Tunisie (Túnez), V (1957), pp. 203-252, traducido y presentado en francés en «Contribution à l'étude des immigrations andalouses et leur place dans l'histoire de la Tunisie», por EPALZA y PETIT, op. cit., pp. 23-63. Cuando se publicó en el Reino Unido un volumen de las principales publicaciones sobre la España musulmana y el Magreb J.D. LATHAM, From Muslim Spain to Barbary. Studies in the History and Culture of the Muslim West, Londres, 1986), se prefirió reproducir la traducción francesa y no el original en inglés. Era obvio, y de la Serna lo había visto.

46. A. DE LA SERNA, Imágenes de Túnez, pp. 237-272.

47. Véase mención expresa de ese precedente en R. GIL GRIMAU, «Documentación sobre moriscos en relación con Marruecos», en A. TEMIMI (ed.), Actes du II Symposium International de C.I.E.M.: Identité, Religion et Sources Documentaires sur les Morisques Andalous Túnez, 1984, 3 vols., tomo I, pp. 349-359 (pp. 349-350, que se reproducen más adelante). 
en ese país de las emigraciones hispánicas, desde Al-Ándalus hasta nuestros días. El trabajo prospectivo de todas esas huellas lo encargó al notable arabista Dr. Rodolfo Gil Grimau, hijo del también escritor "marroquinista" andaluz Rodolfo Gil Benumeya (Andújar, 1901-1975) ${ }^{48}$. El embajador Alfonso de la Serna haría, como en Túnez con el libro de Epalza y Petit, un precioso prólogo al primer volumen de ese libro de Aproximación a una bibliografía española sobre el Norte de África 1850-1980, ya con 16.172 entradas, su introducción y sus índices, del que se hablará más adelante. Ya el título indica que los intereses del embajador y los del autor de la bibliografía desbordaban con mucho, en ese país, a los emigrantes "moriscos" o andalusíes del siglo XVII".

Pero en Túnez Alfonso de la Serna se dedicaría a fomentar otras actividades y publicaciones culturales, que englobarían algunas relaciones con lo morisco pero que desbordaban también el tema de los inmigrantes hispánicos y sus descendientes en el país, que vamos a recordar brevemente.

Finalmente, vería culminada su labor de promoción de los estudios moriscos en el Mágreb por medio de la publicación de investigaciones y estudios, con nuestro nuevo libro y su "Prólogo", aún no publicado ${ }^{50}$.

No puedo dejar de evocar, de paso, cómo el embajador era secundado por su esposa, la embajadora Sra. de la Serna, en su labor de contacto humano con los andalusíes. Una vez tuve la suerte de acompañarla en una visita a uno de los viejos y solemnes palacios de la Medina de la capital, precisamente en la "Rue des Andalous", mansión aún propiedad privada de una descendiente de la ilustre familia de origen granadino Lakhoua ("Los Hermanos") $)^{51}$. Me añadí al cortejo de la Sra. Embajadora y otras damas de la "colonia española", para visitar a la Sra. Lakhoua, que estaba rodeada de otras señoras de su familia, entre ellas una sobrina Lakhoua, experta etnóloga del Institut National du Patrimoine. Durante la larga y amable conversación en el centro del patio de su palacio, la venerable Sra. Lakhoua nos explicaba cómo iba preservando, renovando y restaurando su palacio, siempre indagando sobre elementos arqui-

48. Ver su breve necrológica, realizada con material proporcionado por su hijo, en M. DE EPALZA, «Rodolfo Gil Benumeya, escritor arabista», Almenara (Madrid), 9 (1976), pp. 304-305.

49. Véase A. DE la Serna, "Prólogo" en R. GIL Grimau, Aproximación a una bibliografía española sobre el Norte de África 1850-1980, Madrid, 1982, vol. 1, pp. 9-22.

50. Véase M. de Epalza y A. Gafsi Slama, El español hablado en Túnez...

51. Véase amplio estudio, en esta misma revista, del historiador tunecino A.-H. GAFSI SLAMA, «La familia Lakhoua, descendientes tunecinos de moriscos granadinos de los siglos XVIIXVIII, y sus actividades en la industria del bonete chechía», Sharq Al-Andalus. Estudios Mudéjares y Moriscos (Teruel - Alicante), 14-15 (1997-1998), pp. 219-244, y en la también brillante ficción literaria de presentación de la historia cultural de Al-Ándalus a través de un venerable sabio actual de la familia Lakhoua a su familia moderna de la ciudad de Testour, en los dos gruesos volúmenes del historiador español Juan CASTILLA BRAZALES, Andalusíes. La memoria custodiada, Granada, 2004. 
tectónicos tradicionales de ese viejo barrio señorial, elementos que iba adquiriendo de las obras de edificios vecinos (muebles, maderas, baldosas, estucos, pinturas diversas,...) renovando así su propio edificio con piezas antiguas. Atraía así el interés de todos y las oportunas preguntas de la embajadora Ana Inciarte.

Después de esa visita, a veces coincidíamos, la Sra. Lakhoua y yo, los sábados por la tarde, en la sociedad filarmónica Ar-Rashidiyya, en el centro de la capital, en las sesiones de música andalusí o malouf. A la salida, la venerable anciana, cubierta del tradicional y amplio velo blanco safsari, que le recubría todo el cuerpo y casi toda la cabeza, me saludaba con un simple guiño, al que yo respondía con una ligera inclinación del cuerpo, igualmente amable y silenciosa. Entre "andalusíes" y "andalusistas", como querría Don Alfonso.

\section{Su IMÁGENES DE TúNEZ, LOS COLOQUIOS HISPANO- TUNECINOS Y LA ANTOLOGÍA DE ESTUDIOS MORISCOS}

En este breve repaso de la actividad, discreta e inteligente, del embajador Alfonso de la Serna, durante su embajada en Túnez, especialmente centrada en el recuerdo de los moriscos y de sus descendientes andalusíes, queremos precisamente señalar tres líneas de publicaciones, mutuamente complementarias:

$1^{\circ}$ Plasmar en un libro suyo el conjunto de sus reflexiones sobre la historia común hispano-tunecina y sobre los lugares del territorio tunecino que la recuerdan: Imágenes de Túnez ${ }^{52}$. No se limita en ese libro al tema morisco sólo, sino que abarca también a otras regiones donde no se asentaron esos "hispanoárabes" del siglo XVII y a otras épocas de la historia mutuamente relacionada de ambos países ${ }^{53}$.

52. A. DE la SERnA, Imágenes de Túnez... El libro está significativamente dedicado "A mi amigo Habib", Habib Bourguiba hijo, entonces Ministro de Asuntos Exteriores, hijo del fundador y entonces Presidente de la República Tunecina, del que se ha hablado anteriormente, con una amistad personal indefectible con el matrimonio de la Serna, hasta nuestros días, en que el exministro, además de presentar su pésame a su viuda Ana Inciarte y de haber participado en el Homenaje de la revista Awrâq, le ha ido enviando los recortes de prensa tunecina referentes al óbito de D. Alfonso.

53. Evidentemente, por su cargo oficial y por la ideología franquista del gobierno español de entonces, que él representaba, no podía abordar fácilmente el tema del episodio de la armada de la República Española, que al final de la llamada guerra civil zarpó de Cartagena hacia el puerto militar tunecino de Bizerta, donde se refugió poniéndose en manos de las autoridades francesas del "Protectorado". El gobierno francés entregó las naves al gobierno de Franco y dio cierta opción a los oficiales y a la marinería a que se quedaran en territorio tunecino (alrededor de un $20 \%$, de unos 4.000 militares) o a volver a España. La documentación tunecina sobre ese episodio histórico ha sido objeto de una tesina (Universidad de Túnez) por el ahora Dr. Gafsi Slama, que ha publicado dos trabajos en revistas universitarias españolas sobre ese 
$2^{\circ}$ Fomentar los estudios sobre la historia hispano-tunecina con unos encuentros de expertos, cada tres años, alternativamente en Túnez y en España, y haciendo publicar sus actas: las Actas de los Coloquios Hispano-Tunecinos de Estudios Históricos ${ }^{54}$.

Es interesante ver los títulos de los trabajos publicados en las actas de esos encuentros, para ver la amplitud de los temas y el alto nivel universitario de los investigadores participantes. En la imposibilidad de hacerlo en el marco de este estudio, se van a presentar al menos las referencias bibliográficas de los volúmenes de las actas publicadas y -en nota- algunos datos numéricos, seguidos de la relación de los autores y un resumen de los temas ${ }^{55}$.

Colloque sur les relations historiques et culturelles tuniso-espagnoles (Hammamet 21-24 mars 1969) ${ }^{56}$ [coord. Paul Sebag].

Actas del II Coloquio Hispano-Tunecino de Estudios Históricos (Madrid / Barcelona, mayo de 1972) ${ }^{57}$ [coord. Pedro Martínez Montávez].

Actes de la 3ème Rencontre Tuniso-Espagnole organisée sous l'égide de la Faculté des Lettres et Sciences Humaines de Tunis, du C.E.R.E.S. et de l'Institut HispanoArabe de Culture. Carthage 11-17 Avril 197758 [no figura el coordinador ¿Muhammad Talbi? ¿Abdulwahab Bouhdiba?].

Actas del IV Coloquio Hispano-Tunecino. Palma de Mallorca, $1979^{59}$ [coord. Manuela Marín].

tema: «La situación de los refugiados españoles en Túnez entre el 4 de febrero de 1939 y el 18 de julio de 1940, según unos documentos de archivos del gobierno tunecino», Almenara (Madrid), 10 (1976-1977), pp. 91-108, y «De Cartagena a Bizerta. Prolongaciones tunecinas de la Guerra Civil española (1936-1939)», Anales de historia contemporánea (Murcia), 2 (1983), pp. 251-261. Pero me consta que el embajador de la Serna procuró y practicó con esos refugiados un tratamiento correspondiente a sus derechos de naturales (ciudadanos) españoles, discretamente y siguiendo en eso directrices del Ministerio de Asuntos Exteriores, también para situaciones semejantes "del exilio republicano" en otros países.

54. Título del II Coloquio (Madrid / Barcelona, 1972), que puso con exactitud el Prof. Pedro Martínez Montávez, encargado de publicarlo, y que corresponde a su contenido, con ligeros matices.

55. No he podido encontrar la edición ni la documentación de los coloquios $5^{\circ}$ (en Túnez) y $6^{\circ}$ (en España). ¿Se llegaron a publicar?

56. En Les Cahiers de Tunisie (Túnez, Faculté des Lettres et des Sciences Humaines de Tunis), XVIII / 69-70 (1970), pp. 9-169 [17 autores de capítulos, 8 tunecinos, 9 españoles; 12 textos en francés, 5 en árabe, con algunos resúmenes en francés e incluidos el discurso inaugural del Secretario de Estado de Asuntos Culturales y la reimpresión del texto de H.H. Abdel-Wahab, de 1917].

57. Madrid, Instituto Hispano-Árabe de Cultura, 1973, 310 pp. [19 autores de capítulos, 8 españoles y 11 tunecinos; 14 textos en francés, 2 en español, 2 en árabe; palabras inaugurales del Ministro de Asuntos Exteriores Gregorio López-Bravo].

58. Número especial de Les Cahiers de Tunisie (Túnez), XXVI/103-104 (1978), pp. 1-188 (en árabe) +1-227 (en español y en francés); [23 autores de capítulos, 11 tunecinos, 12 españoles; 11 textos en árabe, 8 en francés, 5 en español].

59. Madrid, Instituto Hispano-Árabe de Cultura, 1983, 251 (en escritura latina) + 196 (en escritura árabe) pp. [34 autores de capítulos, 16 españoles, 18 tunecinos; 16 textos en español, 15 en árabe, 3 en francés, 1 en catalán]. 
Le patrimoine andalous dans la culture arabe et espagnole. Actes du VII Colloque Universitaire Tuniso-Espagnol. Tunis 3-10 février 1989 ${ }^{60}$ [coord. Abdulwahab Bouhdiba].

Para valorar un poco, aunque sea superficialmente, la amplitud del movimiento intelectual que promovió con estos encuentros Alfonso de la Serna y en el que se insertan los estudios sobre los moriscos, vamos a presentar, por orden alfabético de apellidos, los nombres de los participantes a esos coloquios, algunos de ellos repitiendo con investigaciones diversas en varios de los encuentros, a lo largo de 20 años (1969-1989):

Investigadores tunecinos: H.H. Abdulwahab, A. Bakir, M.H. Belkhodja, M. Benabdeljalil, M.A. Bouazizi, A. Bouhdiba, H.T. Bouzaouiata, K. Chater, J. Cheikha, A. Chenoufi, A. El Gannouchi, M. El Qadi, A. Gafsi, S. Garab, F. Hamada, R. Hamzaoui, M.H. Hila, J. Janhani, C. Klibi, J. Magid, R. Marzouqui, K. Omran, M. Souissi, M. Talbi, M. Yalaoui y S.M. Zbiss.

Investigadores españoles: J. Aguadé, C. Álvarez de Morales y Ruiz-Matas, M. Barceló, J. Bosch Vilá, E. Calvo Labarta, A. Cano Ledesma, J.R. Castilla, C. Castillo Castillo, R. Castillo Márquez, P. Chalmeta, M. Comes Maimó, M. de Epalza, J.M. Fórneas, M. García-Arenal, S. Gómez Nogales, S. Gibert, M.D. Guardiola, J.H. Hernández López, B. Justel, R. Kuhne, A. Labarta, F. Marcos Marín, P. Martínez Montávez, E. Molina López, M. Ocaña Jiménez, J. Oliver Asín, R. Pinilla, R. Puig, F. Rodríguez Mediano, G. Roselló Bordoy, M.J. Rubiera Mata, C. Ruiz Bravo, J. Samsó, E. Terés, F. Udina Martorell, J. Vallvé, J. Vernet, J.J. Vidal, M.J. Viguera Molíns y M. Villegas.

Mucho más difícil sería presentar la variedad de los temas de investigación hispano-árabes tratados en esos encuentros científicos: los temas alrededor de las relaciones medievales entre Al-Andalus y el Mágreb árabe dominan, evidentemente, tanto entre los universitarios tunecinos como entre los arabistas españoles, mayoritarios entre los participantes; historia en sus diversos períodos y aspectos (desde el s. VIII al XVIII), literatura árabe andalusí y moderna comparadas, lexicografía y onomástica, ciencias físicas y matemáticas y técnicas, medicina y farmacología, música, sociología, filosofía y pensamiento, derecho e instituciones, religión especialmente mística y teología, economía, arqueología y urbanismo, archivos y textos nuevos, numismática, mudéjares y moriscos...

Esta gran actividad y volumen de encuentros y consiguientes publicaciones sólo serían superadas en Tunicia -aunque más especializadas en los moriscos, en España y en la diáspora de su exilio- por la actividad del profesor Abdeljelil Temimi, en la misma línea de la propiciada por Alfonso de la Serna y también financiada en parte por el Gobierno español y apoyada por los su-

60. Tunis, Cahiers du Centre d'Études et de Recherches Économiques et Sociales (CERES) série histoire $\mathrm{n}^{\circ} 4$, Tunis 1991, 120 (en árabe) + 240 (en francés) pp. [ 22 autores de capítulos, 15 españoles, 7 tunecinos; 16 textos en francés, 6 en árabe]. 
cesivos embajadores de España en Túnez, al menos con la compra de ejemplares de sus publicaciones o de financiamiento de los viajes de investigadores españoles a los encuentros científicos, en Túnez y en España.

$3^{\circ}$ Fomentar la investigación sobre los moriscos expulsados de España e instalados en Túnez a principios del XVII y sobre sus descendientes hasta la actualidad, especialmente con el libro que recogió 32 estudios variados sobre ellos: Recueil d'Études sur les Moriscos Andalous en Tunisie ${ }^{61}$, ya mencionado.

Unos años más tarde y una vez fundado el Centro de Estudios HispanoAndalusíes, del Ministerio de Cultura de Túnez, y entre sus primeras actividades y publicaciones se editó un volumen con estructura semejante y 18 estudios más: Etudes sur les Morisques Andalous ${ }^{62}$, de lo que se hablará a continuación, en el apartado siguiente.

\section{ESTUDIOS HISPANO-ÁRABES BASADOS EN LA COOPERACIÓN CON INSTITUCIONES TUNECINAS}

La acción cultural hispano-árabe del embajador Alfonso de la Serna, tanto en Túnez como en Marruecos, no sólo se desarrolló en el día a día de la actividad diplomática, durante los cinco años que él estuvo en la Embajada de España en Túnez. Tuvo una visión de medio y largo alcance para las relaciones entre esos países y España. Por eso fue continuada, con las normales diferencias personales, por los demás embajadores que le han sucedido en el cargo. Y se basó en la cooperación con instituciones tunecinas, tanto estatales como privadas. Expondremos brevemente en este apartado las principales:

$1^{\circ}$ Las instituciones culturales tunecinas precedentes y consolidadas más importantes, dependientes del Ministerio de Educación y del de Cultura, fueron la Universidad de Túnez, especialmente la Facultad de Letras con sus revistas Les Cahiers de Tunisie ${ }^{63}$ y Hawliyyât al-Yâmi'a at-Tûnisiyya (en árabe) ${ }^{64}$, el Centro de Estudios e Investigaciones Económicas y Sociales (CERES) y sus publicaciones, y el Instituto Nacional de Arqueología y Arte (ahora Institut National du Patrimoine) y las suyas, etc.

61. Recogidos por EPAlza y PeTit, op. cit., y presentados uno por uno por Epalza, editado en Madrid, por la Dirección General de Relaciones Culturales, Instituto Hispano-Árabe de Cultura, del Ministerio de Asuntos Exteriores, 1973, 319 pp.

62. Véase ZBiss, GAFsi, Boughanmi y EPAlZA, op. cit. [11 estudios en francés, 4 en español y 3 en árabe, con resúmenes en árabe y en francés].

63. Véase, para los coloquios y la publicación de sus actas, el apartado precedente.

64. Véase, para los principales artículos publicados en aquella época (1964-1994), la presentación de M. DE EPALZA, «Lo andalusí y lo español en una revista tunecina moderna. 30 años de Hawliyyât al Yâmi'a at-tûnisiyya», Awrâq (Madrid), XV (1994), pp. 251-269. 
$2^{\circ}$ Alfonso de la Serna fomentó la creación del Centro de Estudios Hispano-Andalusíes, para dar permanencia institucional a esos estudios en el Instituto Nacional del Patrimonio. Para ello contó con la inestimable competencia de Slimane Mustapha Zbiss, antiguo director general de ese Instituto y de la Sección de Manuscritos de la Biblioteca Nacional, él mismo de familia andalusí y originario de la pequeña ciudad de Testour, re-fundada por los moriscos ${ }^{65}$.

Ese Centro acogió y formó a unos jóvenes investigadores tunecinos que prosiguieron y acrecentaron notablemente su actividad investigadora y de publicaciones: Abdelhakim Gafsi Slama, Muhiedine Boughanmi (Benali), Nureddin Hlaoui... Les inició científicamente, así como a su hija etnóloga Nabila Zbiss, e hizo trabajar en diversos campos de investigación sobre los moriscos o andalusíes y sobre sus huellas en la capital y en diversas regiones del norte del país, con el asesoramiento universitario de los profesores Abdeljelil Temimi y Míkel de Epalza. Tras la jubilación laboral del Sr. Zbiss, el Centro pasó por diversos avatares hasta desaparecer, pero esos investigadores permanecen en el Instituto como funcionarios.

Mi modesta cooperación a esa labor, ya desde Argelia o desde España, cuando ya el embajador Alfonso de la Serna y yo no residíamos en Túnez, consistió principalmente en participar en las tres primeras publicaciones del Centro $^{66}$ y en contribuir a formar a esos jóvenes investigadores con investigaciones bibliográficas ${ }^{67}$ y buscando dónde publicar en España los resultados de sus monografías investigadoras. Es una labor que me honro en seguir haciendo, con la colaboración personal y de difusión en España en el caso de los

65. Véase, más adelante, el apoyo del embajador de la Serna a este notable historiador y arqueólogo tunecino, también especialista en los moriscos instalados en Túnez y sus descendientes, Académico corresponsal de la Real Academia de la Historia de Madrid, etc. Véase también las notas necrológicas de M. DE EPALZA, «Ilmo. Sr. Slimane-Mustafa Zbiss (1913-2003). Bibliografía del Sr. Zbiss sobre Mudéjares y Moriscos», Aljamía. Anuario de información bibliográfica. Mudéjares - Moriscos - Textos aljamiados - Filología Árabo-Románica (Universidad de Oviedo), 16 (2004), pp. 46-51, y «Fallecimiento del historiador tunecino, descendiente de moriscos, Ilmo. Sr. Slimane-Mustafa Zbiss», Sharq Al-Andalus. Estudios Mudéjares y Moriscos (Teruel - Alicante), 16-17 (1999-2002), pp. 377-360.

66. Véase M. DE Epalza, M. Boughanmi y A. GAFsI, Bibliographie tunisienne concernant l'histoire de l'Espagne (1956-1973), Túnez, 1975; M. DE EPALZA, Bibliographie algérienne concernant l'histoire de l'Espagne (1962-1973), Túnez, 1976 y ZBiss, BoughanMI, GAFSI y EPALZA, op. cit.

67. Estudio bibliográfico que se fue realizando a un tiempo en Túnez -con los jóvenes historiadores del Centro Gafsi (Gafsi Slama) y Benali (Boughanmi)- y en Argelia, en los años 1973 y 1974, en que iba alternando cursos y cursillos universitarios en las universidades de ambos países, primero en Túnez y luego en Argel y Orán. Dio origen a cuatro publicaciones: M. DE EPAlZA, M. BOUGHANMI y A. GAFSI, «Producción tunecina y argelina sobre historia de España desde la independencia (1956 y 1962)», Indice histórico español (Barcelona), vol XV, n 56bis (1965) [1975], pp. XI-LXII; traduciéndose al francés la parte tunecina en EPALZA, BEN ALI y GAFSI, Bibliographie tunisienne..., con dos versiones de la parte argelina, M. DE EPALZA, Bibliographie algérienne..., e ID., Ecrits relatifs à l'histoire de l'Espagne publiés en Algérie de 1962 à 1973, Argel, 1976. 
muchos trabajos de calidad de Abdelhakim Gafsi Slama, que aporta siempre documentos nuevos y valiosos sobre moriscos y otros temas, bien analizados y sintetizados ${ }^{68}$.

Es bien sabido que el trabajo de recoger bibliografía (y leerla..., contrastando el valor de cada publicación) es un paso prioritario para cualquier investigación o conocimiento de un tema, como nos cuenta el propio embajador De la Serna de sus lecturas en España antes de ir a su destino diplomático de Túnez, en el largo texto sobre su entrevista con Hasan Husni Abdelwahab reproducido ya en este artículo. Por eso apliqué esa técnica con los jóvenes investigadores tunecinos, y de paso haciéndoles publicar los resultados, para otros lectores e investigadores ${ }^{69}$. También lo había hecho yo con Ramón Petit, al iniciar el libro sobre los moriscos, por encargo de Alfonso de la Serna ${ }^{70}$. Lo hice, asimismo, al iniciar mi trabajo en las universidades de Argelia (1972-1974) ${ }^{71}$ y hasta al iniciar mi trabajo en la región de Alicante $(1979)^{72}$. Ese trabajo bibliográfico permite, a su vez, conocer a las personas y las instituciones interesadas o capaces de interesarse por el mundo cultural hispánico y poder así "hacerse el encontradizo" con ellas y preparar nuevas iniciativas investigadoras o culturales en general. Alfonso de la Serna utilizó mucho estas informaciones en su labor de diplomacia cultural hispano-árabe, gracias a la gran capacidad de su curiosidad intelectual y de su trato, cercano y distinguido.

Hasta el final de su vida el Sr. Zbiss siguió trabajando, completando sus libros y sus amplios archivos fotográficos sobre restos del pasado y especialmente de restos de obras dejadas presuntamente por los moriscos y sus descendientes andalusíes $^{73}$. En estos últimos años se consagró particularmente a ayudar a su hija etnóloga, formada científicamente en la Universidad de París, a ir publicando listados de apellidos o nombres de familias de origen hispánico, de andalusíes tu-

68. Véase algunos de ellos en las notas de este artículo y la participación del Dr. Slama en el volumen de homenaje a D. Alfonso de la Serna de la revista Awrâq, publicado en francés en la prensa tunecina: A. GAFSI SLAMA, «Homenaje póstumo. Tunicia acaba de perder a un gran amigo: Alfonso de la Serna», Awrâq (Madrid), XXIII (2006), pp. 197-199.

69. Al ser un Centro dependiente del Ministerio de Cultura, sus publicaciones figuran a la entrada del Museo Nacional del antiguo palacio beylical de El Bardo, en las afueras de Túnez, visitado por miles de turistas tunecinos y extranjeros, y tienen por eso una difusión mucho mayor que el de otras instituciones.

70. Véase primer capítulo de R. PetiT, «Bibliographie générale», en EPALZA y PETIT, op. cit., pp. 9-15.

71. Véase M. DE EPALZA, Bibliografía argelina... y Ecrits relatifs...

72. Véase M. DE Epalza, M.J. Paternina y A. Couto, Moros y moriscos en el Levante peninsular (Sharq Al-Ándalus). Introducción Bibliográfica), Alicante, 1983, y J.L. ROMÁN DEL CERRO y M. DE EPAlZA, Toponimia mayor y menor de la provincia de Alicante. Listado por municipios, Alicante, 1983.

73. Véase volumen de Homenaje Mélanges d'Archéologie, d'Épigraphie et d'Histoire offerts à Slimane Mustapha Zbiss, Túnez, 2001, y su biobibliografía en M. DE EPALZA, «Necrológica. Ilmo. Sr. Slimane-Mustafa Zbiss...» e ID., «Fallecimiento del historiador...». 
necinos, de las más diversas fuentes ${ }^{74}$. Pocos meses antes de su fallecimiento y a petición de la catedrática Rubiera Mata, directora del portal digital "Literatura de mudéjares y moriscos" de la Biblioteca Virtual "Miguel de Cervantes Saavedra” (BIMICESA), de la Universidad de Alicante y la Fundación Botín, se pidió al Dr. Slama que entrevistara al Sr. Zbiss sobre sus investigaciones y recuerdos familiares sobre esos moriscos o andalusíes, vídeo que está por tanto en la red de Internet y también impresa en las Actas de un congreso internacional ${ }^{75}$ y en el libro en preparación ya mencionado de Epalza y Gafsi ${ }^{76}$.

No en vano Alfonso de la Serna había confiado en este singular personaje andalusí, descendiente de moriscos del XVII instalados en la pequeña capital comarcal de Testur, de repoblación morisca, y singular investigador y brillante funcionario del Ministerio de Cultura de Túnez. De él escribía: "Conocí singulares personalidades tunecinas que me ilustraban en la materia. Uno de esos amigos fue el querido, sabio y entrañable Mustafá Slimane Zbiss, a cuya memoria se rinde homenaje en este libro" ${ }^{\prime 77}$.

$3^{\circ}$ Apoyo al profesor Temimi y a sus iniciativas a favor de los congresos e investigaciones sobre la historia de los moriscos. El embajador A. de la Serna y sus sucesores apoyaron esas iniciativas del profesor universitario de historia moderna y contemporánea (siglos XVI-XX) Abdeljelil Temimi, que había iniciado en 1973 su novedosa revista Revue d'Histoire Maghrébine y haría de Túnez, Zaghouan y ahora en una zona al norte de Túnez un importante centro de estudios sobre los moriscos ${ }^{78}$. Como presidente del Comité Internacional de Estudios Moriscos, fundado en el Encuentro de Montpellier ese año, Temimi organizó y sigue organizando encuentros y publicaciones científicas sobre temas moriscos, dentro de una temática general de ese período histórico, otomano y actual $^{79}$. Temimi heredó en parte de la época de A. de la Serna el impulso de la

74. Véase N. ZBISS, «L'Onomastique espagnole en Tunisie», Sharq Al-Andalus. Estudios Árabes (Alicante), 7 (1990), pp. 215-219, e ID., «La Tunisie, terre d'acceuil des morisques venus d'Espagne au début du XVIIe siècle», en A. TemIMI (dir.), Actes du IV Symposium Internationnal d'Etudes Morisques sur: Métiers, vie religieuse et problématiques d'histoire morisque, Zaghouan, 1990, pp. 337-342.

75. Véase versión digital en y texto impreso de la entrevista en francés traducido al castellano en A. GAFSI SLAMA y M. DE EPALZA FERRER, «Entrevista al Sr. Zbiss y a su familia sobre los moriscos y sus descendientes en Tunisia», IX Simposio Internacional de Mudejarismo. Mudéjares y moriscos. Cambios sociales y culturales. Teruel, 12-14 de septiembre de 2002. Actas, Teruel, 2005, pp. 437-447.

76. Véase M. de Epalza y A. Gafsi Slama, El español hablado en Túnez..., "Apéndice 1".

77. Del "Prólogo" de Alfonso de la Serna, de 2005, al libro de M. DE EPAlZa y A. Gafsi SlamA, op. cit. [aún inédito].

78. Véase M. DE EPAlZA, «Congresos y publicaciones de Historia árabe en época otomana (Túnez)», Awrâq (Madrid), IX (1988), pp. 217-222.

79. Tiene convocado para 2007 el XIII Simposio Internacional de Estudios Moriscos, sobre "Las huellas orientales y las dimensiones ideológicas y políticas en la literatura aljamiado-morisca" y "La institución de la Inquisición en relación con los expedientes de la comunidad morisca de los siglos XVI y XVII en España, en América Latina y más allá..." (Fundación Temimi, Túnez, 2-5 de mayo de 2007). 
celebración de coloquios y de publicaciones diversas alrededor de los moriscos y sus descendientes andalusíes (monografías, traducciones más o menos abreviadas, misceláneas de homenaje a "moriscólogos" notables... $)^{80}$, con la colaboración de una red internacional de investigadores.

$4^{\circ}$ Revista del Dr. Jomaa Cheikha, profesor de Literatura Andalusí, que había participado en varios de los encuentros universitarios hispano-tunecinos, y que acabó haciendo su propia revista, Dirasat Andalusiyya. Études Andalouses, la principal y más constante revista universitaria dedicada exclusivamente a temas hispano-árabes, en todo el mundo árabe, desde diciembre 1988 / jumada I 1408, con varios números al año (en árabe, en español, en francés y en inglés).

Aunque no esté centrada tampoco en los moriscos exclusivamente, sino que tiene artículos de tema andalusí y temas hispano-árabes en general, como los mencionados simposios, trata a veces de temas específicamente moriscos. Está especializada también en dar noticias sobre lo andalusí y la actualidad cultural hispano-árabe (congresos, tesis y tesinas, conmemoraciones históricas...). Se fundó cuando el embajador de la Serna ya no estaba en Túnez, pero puede legítimamente decirse que siguió y sigue el empuje que él dio en Túnez a las publicaciones sobre la historia y cultura hispano-árabes, con el apoyo y ayuda de sus sucesores en la Embajada, hasta hoy en día.

\section{BAJO LA EXPERIENCIA DE DE LA SERNA, PERO POR CAMINOS DIFERENTES}

Esta multiforme e inteligente actividad, impulsada por A. de la Serna, estaba destinada a permanecer, de una u otra forma. Impulso suyo es también, al fin y al cabo, el libro ya mencionado, de Epalza y Gafsi Slama, El español hablado..., con prólogo suyo, que aparecerá seguramente 40 años después de su llegada a Túnez en 1968 y de su visita a Hassan Hosni Abdelwahab.

Después de 1973, nuestros caminos se separaron: él fue destinado de embajador en Suecia y yo obtuve un contrato de profesor en las universidades argelinas de Argel y Orán (1973-1974). Él tenía 51 años y yo a mis 35 años salía de los dos años de la experiencia tunecina con más madurez profesional. Luego él volvió a la Dirección General de Relaciones Culturales, en Madrid (19761977), y fue destinado a la Embajada de España en Marruecos (1977-1983), donde volvió a intensificar su estudio y su labor sobre el mundo árabe y musulmán, pero con enfoques nuevos y diferentes. Marruecos es un país culturalmente árabe y musulmán, magrebí, como Túnez, pero el país y sus relacio-

80. En 2003 ya eran 23 libros, según A. Temimi, Hommage à l'Ecole..., pp. 467-468 (francés), 81-82 (árabe). 
nes políticas con España eran diferentes. Yo volví a la Universidad española, en Madrid (Universidades de Madrid-Autónoma y Madrid-Comillas, 1974-1978) y finalmente en Alicante. Durante casi 20 años nuestros contactos fueron más esporádicos, pero siempre respetuosos y amistosos.

Y al llegar a Alicante en 1979 hasta tuve la ocasión de publicar un articulito en una revista regional de la Caja de Ahorros de Alicante, sobre un encuentro con el historiador alicantino y Académico de la Historia almirante Julio Guillén Tato, con motivo del espectáculo que el embajador de España Alfonso de la Serna había organizado para presenciar la fiesta y caza-pesca de atunes, en el Festival Anual de la almadraba de Sidi Daoud, en la costa noreste de Túnez, pesca como la que el almirante Guillén había visto de niño, décadas antes, en el pueblo costero de Benidorm, de donde él era natural. ¡Brillantísimos ambos, el espectáculo marítimo y el conversador almirante!, con la grata presencia de los anfitriones, los tunecinos y el matrimonio de la Serna ${ }^{81}$. No iba exento de negocio la presencia del embajador de España y del almirante, en la pesca marítima. Lo pude constatar un día desde la ventanilla de la ducha del Club Náutico de Palma de Mallorca desde donde vi la proa de un barco de pesca de los astilleros del puerto, con el nombre -en escritura árabe y en española- de un pueblo tunecino repoblado por moriscos andalusíes ("Testur", pero había otros dos pesqueros, "Solimán" y "Zaguán"), fruto de un sustancioso acuerdo hispano-tunecino de renovación de la flota pesquera de la República Tunecina. Alfonso de la Serna cuenta cómo en esa jornada marítima, "en el verano de 1971, dirigían las operaciones unos capitanes de almadrabas españoles, que venían de la costa de Alicante, contratados por la empresa estatal tunecina Office National des Pêches [...] cruzando todo el golfo [de Túnez] en una lancha rápida de la Marina de guerra tunecina" ${ }^{82}$. Pero hasta en la operación comercial de venta de barcos pesqueros de España a Túnez supo introducir un toque cultural "andalusí", con los nombres de los buques, en memoria de los moriscos, tan recordados por los tunecinos.

He mencionado ya algo de lo mucho que aprendí a apreciar la labor de los diplomáticos y en particular de grandes embajadores que conocí en los países árabes, como Los Arcos, Aguirre de Cárcer y singularmente Alfonso de la Serna. En mis sueños de adolescente quería ser diplomático por lo mucho que viajaban. Luego me di cuenta de lo duro de ese oficio, soportando los problemas de los españoles en esos países extranjeros e intentando resolver los conflictos entre intereses de grupos diferentes y entre diversos países. Pero en aquellos años de más madurez, en países árabes, admiré un singular aspecto de

81. Véase M. DE EPALZA, «Alfonso de la Serna. El almirante alicantino Julio Guillén, en Túnez», Idealidad (Alicante), 18 (julio-agosto-septiembre 1979), p. 37, texto que envié a D. Alfonso inmediatamente, cuando se publicó.

82. A. DE LA SERNA, Imágenes de Túnez..., pp. 139-140. 
su trabajo, auténtico "privilegio" de esos embajadores. En su trabajo se veían en la situación de tener que tratar, por una parte, con "las élites" del país donde representaban a España y, por otra, a conocer a grandes personalidades españolas de visita a esos países (a nivel político, económico, empresarial, intelectual, administrativo, artístico, etc.). Y para eso estaban formados por la "carrera diplomática". Claro que conocí a embajadores que no eran "diplomáticos de carrera" ${ }^{83}$, pero -como reflexión audaz, por lo escaso de mi experienciapensé muchas veces que al refrán latino "Quod natura non dat, Salamanca non prestat", se podría añadir que "Quod Salamanca non dat [los estudios y prácticas de la "carrera"], natura non prestat [el talento natural no basta]".

\section{ADAPTAR LA EXPERIENCIA TUNECINA A OTROS PAÍSES: Argelia, Madrid, Alicante}

Esa experiencia tunecina con Alfonso de la Serna me resultó muy provechosa en mi estancia argelina. Su imagen y actuación estuvo a menudo presente para mí, desde que nos despedimos uno y otro de Túnez, casi al mismo tiempo. No voy a exponer aquí todo lo diferente que fue mi actividad en Argelia. Ni sé gran cosa de la actividad en Marruecos de Alfonso de la Serna, aunque algo se da a conocer en sus escritos. Pero, con la perspectiva del tiempo transcurrido, veo que practiqué modestamente en mis tres etapas profesionales posteriores (Argelia, Madrid, Alicante), a grandes rasgos, consciente o inconscientemente, lo que había aprendido en Túnez, con Alfonso de la Serna. Se resume, esquemáticamente, en cuatro etapas, para cada trabajo nuevo:

$1^{\circ}$ Estudiar la bibliografía, para preparar el trabajo y saber a quién puede interesar.

$2^{\circ}$ Conocer a esas personas, visitándolas o "haciéndome el encontradizo".

$3^{\circ}$ Hacer reuniones o equipos de esos expertos, para un trabajo en equipo, con cada uno.

$4^{\circ}$ Publicar lo mejor de ese trabajo, siempre en la medida de lo posible.

$Y$ he de confesar que a menudo me preguntaba "¿Qué pensaría de esto el embajador De la Serna?".

Por tanto, tras haber visto lo hecho en Túnez, dejaré de exponer mi trabajo con D. Alfonso y resumiré brevemente algo de lo que veo que él hizo en y tras su estancia en Marruecos.

83. Particularmente a un catedrático de universidad, de Letras, y a un político y empresario, amigo y vecino de infancia de mi madre y de mis tíos. 


\section{MARRUECOS: LA COMPLEJIDAD DE LAS “DOS ORILLAS"}

No me voy a detener en la estancia y la actividad de Alfonso de la Serna en su embajada en Marruecos. Sólo la he seguido desde lejos. Otros hay que hablarán con más competencia y cercanía, en el volumen de la revista Awrâ $q^{84}$. Pero no me puedo resistir a comentar algunos aspectos que he podido otear, desde lejos y leyendo algunos de los escritos que él dedicó a Marruecos.

Lo que advirtió seguramente Alfonso de la Serna, muy pronto, es la complejidad de ese país ${ }^{85}$. De ahí su interés, a nivel cultural, por el trabajo bibliográfico del Dr. Rodolfo Gil Grimau por recoger las publicaciones en español (y en algunas otras lenguas) sobre las relaciones hispano-marroquíes (luego ma-

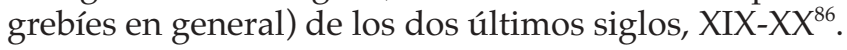

En eso, ambos coincidían seguramente con el padre de Gil Grimau, el escritor andaluz Rodolfo Gil Benumeya (Andújar, 1901-1975), ya desde el título evocador del primer libro de éste, en que expresaba su visión de las relaciones hispanomarroquíes: Mediodía. Introducción a la historia andaluza $(1975)^{87}$. Su hijo tiene también un libro con título que recuerda la misma visión que el del libro de Alfonso de la Serna, Al sur de Tarifa. Marruecos-España: un malentendido histórico ${ }^{88}$, porque la coincidencia de visión corresponde seguramente a que la realidad es la misma ${ }^{89}$. Coincidencia de tema, pero variedad de enfoques y matices, también.

84. Véase, en particular, A. MARTINELL SEMPERE, "Presentación”, «Alfonso de la Serna y GutiérrezRépide», Awrâq (Madrid), pp. 179-180, 181-182; R. GIL BENUMEYA GrIMAU, op. cit., pp. 183-187; J. ORTEGa SAlinAS, op. cit., pp. 189-192; O. AzZIMAN, «Homenaje a Don Alfonso de la Serna», pp. 193-195; M. DE EPALZA, «Breve estudio...», pp. 201-217; V. MORALES LEZCANO, «In memoriam (Alfonso de la Serna)», pp. 221-225; M. HERNANDO DE LARRAMENDI y B. LÓPEz GARCíA, «Alfonso de la Serna y la edición de temas magrebíes en España», pp. 227-229.

85. Es una impresión comparativa que tuve yo también, cuando preparaba mi tesis doctoral (1964-1966) y di dos veces la vuelta de los países árabes de las costas este y sur del Mediterráneo. Simplificando, vi que habría dos países árabes que nunca acabaría de comprender, Egipto porque era muy grande y Marruecos porque era muy complicado. Suponiendo que se pueda comprender suficientemente un país...

86. Véase R. GIL GRIMAU, Aproximación a una bibliografía española..., con la presentación de A. DE LA SERnA, "Prólogo".

87. Véase breve necrológica, redactada con ayuda de material proporcionado por su hijo, en M. DE EPAlzA, «Rodolfo Gil Benumeya, escritor arabista», Almenara (Madrid), 9 (1976), pp. 304-305.

88. Curiosamente, la portada exterior pone...Marruecos-España... y la interior...España-Marruecos... Muchos creemos que no es lo mismo: los marroquíes en general conocen mucho mejor a los españoles que al revés, aunque sólo sea por la vía cinematográfica y televisiva, desde Canarias o desde la Península, dominada por la visión de la sociedad occidental, que forma también parte de la propia sociedad marroquí.

89. R. Gil Grimau, La Frontera Sur de Al-Andalus: Estudios sobre la Península Ibérica y sus relaciones históricas con Marruecos, Tánger, 2002. Véase también el peso de las tradiciones "moriscas" o árabehispánicas, como las recoge en florilegio R. GIL GRIMAU, «Sobre la diáspora y la ocultación moriscas dentro de su patria. Hechos y recuerdos por vía verbal», en A. TEMIMI (dir.), Hommage à l'École..., pp. 249-256. 
Viniendo con su experiencia de Túnez, del peso de la herencia morisco-andalusí de la emigración del siglo XVII, era normal que Alfonso de la Serna se interesara al principio prioritariamente en Marruecos por esa emigración en el extremo oeste del magreb, con una importancia histórica tan notable en las ciudades portuarias de Rabat-Salé y de Tetuán, tema estudiado en particular por el Dr. Guillermo Gozalbes Busto ${ }^{90}$, en las últimas décadas del siglo XX, y por tantos otros, marroquíes (como el hispanista profesor Hossain Bouzineb y los historiadores Muhámmad Ben Azzuz Hakim y los profesores Ahmed Boucharb y Muhámmad Razuq, y muchos otros) y extranjeros, especialmente españoles y franceses.

Pero en el "andalusismo" de la sociedad marroquí pesa mucho más todos los casi 1.300 años de historia árabe alrededor del Estrecho, "entre las dos orillas" (bayna al-'idwatayn o al-'udwatayn) ${ }^{91}$, la del Mágreb y la de la Península Ibérica, especialmente cuando las dos orillas estaban habitadas por árabes, de Al-Magreb y de Al-Ándalus. Esta historia alrededor del Estrecho (al-madîq o az-zuqâq) es estudiada por los historiadores marroquíes como parte importante de la historia propia (como por los profesores Muhámmad Bencherifa, Muhámmad Bennaboud y otros muchos) y engloba a todo lo "hispano-árabe" árabe e islámico sin excluir las relaciones entre el Marruecos musulmán y la España cristiana, como es el tema de los moriscos, de su emigración y su definitiva expulsión y de sus descendientes directos y de las huellas específicas que éstos han podido dejar en ese país. En la sociedad marroquí es, por otra parte, más difícil que en la tunecina determinar las aportaciones de las emigraciones andalusíes del período morisco del XVI-XVII, en hispanismos de lengua, tanto de léxico como de onomástica, o en arquitectura, agricultura, alimentación, artesanías varias, etc. Las influencias hispánicas se extienden a lo largo de muchos siglos y hasta nuestros días. Hay, por tanto, mucho ucronismo que permite toda clase de hipótesis sobre su origen y datación, mucha dificultad en probar y fechar históricamente.

El Dr. Rodolfo Gil se había dado cuenta de esa dificultad de delimitar lo perteneciente a la influencia morisca en todo lo hispánico conservado en la sociedad marroquí: ¿era pre-morisco medieval hispánico? ¿de influencia de los presidios y de los mogataces ${ }^{92}$, de su entorno geográfico? ¿de época moderna mediterrá-

90. Véase M. DE EPALZA, «Biobibliografía de Guillermo Gozalbes Busto (1916-1999)», Sharq AlÁndalus. Estudios Mudéjares y Moriscos (Teruel - Alicante), 14-15 (1997-1998) [2002], pp. 311-318, realizada con la fundamental ayuda de sus hijos Carlos y Enrique Gozalbes Cravioto, también historiadores de las relaciones hispano-árabes y especialmente de Marruecos.

91. Véase la reciente y documentada monografía de E. LAPIEDRA, «Al-'Idwatayn: espacios y fronteras entre al-Andalus y el Mágreb», en A.I. Planet y F. Ramos (coords.), Relaciones HispanoMarroquíes: Una Vecindad en Construcción, Guadalajara, 2005, pp. 19-34.

92. Véase la definición de este arcaísmo de la lengua española: "mogataz. (Del árabe mugattas, bautizado) adjetivo. Véase moro mogataz" y "moro de paz, moro marroquí que servía de intermediario para tratar con los demás moros en los presidios españoles de África [...] moro mogataz. Soldado indígena al servicio de España en los antiguos presidios de África", según Diccionario de la lengua española. Real Academia Española, Madrid, 21ª edición, 1992, tomo II, pp. 1387 y 1403. 
nea? ¿del período colonial hispano-francés del siglo XX y de la inmigración hispánica que provocó? ¿de la emigración militar y laboral marroquí a España de mediados del siglo XX? ¿de la migración de tránsito actual hacia Europa y reflujo a su tierra, de cada año? ¿de influencia francesa reciente o italiana? ¿de la influencia de los medios de comunicación, especialmente radio y televisión? ${ }^{93}$.

El proyecto de libro de Rodolfo Gil correspondería al primer interés y curiosidad de Alfonso de la Serna, cuando éste llegó a la embajada de Rabat, en 1977, con su experiencia tunecina y después de sus estancias como embajador en Suecia y como director general de Relaciones Culturales -por segunda vezen Madrid. El proceso de ampliación de ese proyecto, desde su forma tunecina a la ampliación de perspectivas marroquíes, viene contado escuetamente por el Dr. Gil Grimau:

"Es evidente que se impone estudiar a fondo el problema de los moriscos en Marruecos. La necesidad de emprender, o reemprender, una serie de estudios sobre la llegada, actividades, peso específico y social, idioma e influencias históricas de la emigración morisca en Marruecos se hace patente e incluso urgente. Como es sabido, la bibliografía de los estudios referentes a los moriscos en la sociedad y en el estado marroquíes, es virtualmente escasa; y, en su mayor parte, algo antigua. Durante algún tiempo, yo mismo y un pequeño equipo, tuvimos la idea de reunir todo este material de estudios publicado y volverlo a editar en su conjunto, de tal forma que pudiera disponerse de él en un volumen de impresión reciente y de fácil adquisición. La idea era, en realidad, la de repetir, en lo concerniente a Marruecos, la misma idea y proyecto que dieron como resultado el libro de Míkel de Epalza y Ramón Petit, Receuil d'études sur les Moriscos andalous en Tunisie, publicado en 1973; y espléndidamente continuado por Sliman Moustapha Zbiss y sus colaboradores.

A este efecto, [sigue la descripción del proceso de realización de ese proyecto, que resultó decepcionante, y su abandono para proseguir con el que tenía que desembocar en el volumen Aproximación a una bibliografía española...], el primer hilo de los cuatro o cinco volúmenes que va a constar la obra, con un total de unas 80.000 referencias bibliográficas aproximadamente" ${ }^{\prime \prime 4}$.

La ampliación o modificación del proyecto era ineluctable, tratándose de Marruecos, sin dejar de atender específicamente a la investigación de las emigraciones de moriscos a esas tierras, en los siglos XVI-XVII ${ }^{95}$. La proximidad del

93. Se han tratado estas cuestiones, brevemente, en el capítulo sobre la diáspora morisca "1.2.10.3. Moriscos en Marruecos", en M. DE EPAlZa y A. GAFSI Slama, El español hablado en Túnez...

94. R. GIL GRIMAU, «Documentación sobre moriscos...», pp. 349-350. Por información posterior del propio autor, está en imprenta un volumen que recoge el material del primero y de un segundo tomo: Aproximación a una bibliografía española sobre el Norte de África, Tomos I y II, y sobre Al-Ándalus.

95. Véase ya R. GIL GrimaU, «Necesidad de unos estudios sobre los moriscos en Marruecos», Rabat, 1978, (multicopista, 11 pp.); reproducido en ZBISS, GAFSI, BOUGHANMI y Epalza, op. cit., pp. 251-262. 
"Sur" y del "Estrecho" son realidades geográficas y político-culturales bastante difíciles de comprender en profundidad, aunque se quiera que sean «Un Estrecho sin orillas espirituales» donde domine «La filosofía y el pensamiento sin fronteras», como intenta describirlo, en su complejidad, el profesor Pacheco Paniagua, arabista, pensador y escritor de la Universidad de Sevilla ${ }^{96}$.

Alfonso de la Serna, al principio y al final del prólogo que redactó para el libro de Gil Grimau, advierte la necesidad urgente del adecuado conocimiento mutuo entre españoles y marroquíes, basándonos en lo que ha sido ya escrito y publicado por los que nos han precedido, desde el siglo XIX:

“[...] con la pasión de quien sabe que está tocando una fibra sensible de un gran cuerpo histórico, de quien se da cuenta de que tiene en las manos un rico tesoro casi inédito, una verdad escondida; algo, en fin, que hay que inventar en el más puro sentido de esta palabra: descubrir" ${ }^{\prime \prime 7}$.

Quien estaba intentando descubrir con pasión el "rico tesoro casi inédito" del pasado, del presente y del futuro hispano-marroquí era el propio Alfonso de la Serna, para transmitirlo en sus escritos ${ }^{98}$.

"Rodolfo Gil, al ofrecernos esta primera parte de su obra, nos pone de nuevo delante de un vasto hecho que esos hondos sentimientos a que me he referido más arriba han intentado más de una vez olvidar o rechazar: que Marruecos está ahí, enfrente de nosotros, desde el fondo de los siglos y ya para siempre, que, como vanguardia geográfica e histórica de África, de la nación árabe y de la comunidad islámica, ha desempeñado y desempeñará una función trascendental en la historia de España; que nos ofrece -por los restos del pasado histórico que aún permanecen entre las dos costas- restos y posibilidades; que todo nos es permitido menos una cosa: ignorarlos.

Las páginas que siguen son prueba de un intento de comprensión por varias generaciones de españoles. Hagámosles el honor de comprender nosotros también este gran vecino nuestro, metido por los azares de la historia en las entrañas mismas del pasado español, tenaz compañero de nuestra vida, encarnizado enemigo a veces, amigo fraternal otras, incomprendido tantas" ${ }^{\prime 99}$.

Rodolfo Gil seguiría, tras su paso como director del Centro Cervantes de Lisboa y su jubilación profesional, ambas líneas de publicaciones: la amplia línea de bibliografía española sobre temas hispano-magrebíes ${ }^{100}$ y la más específica de la historia de los moriscos, antes y después de la expulsión, con dos congresos, en Sevilla la Nueva, al oeste de Madrid, en 1998 y en

96. Títulos de dos de los capítulos del inteligente libro de J.A. PACHECO, Andalucía y Marruecos. Culturas para el diálogo, Sevilla, 2004, sobre temas semejantes, sobre todo históricos, pero también con el capítulo final "De la historia a la realidad: Andalucía y Marruecos hoy" (pp. 165-177).

97. "Prólogo" a R. GIL Grimau, Aproximación a una bibliografía..., p. 9.

98. Véase especialmente A. DE LA SERnA, Al sur de Tarifa...

99. R. Gil Grimau, Aproximación a una bibliografía..., pp. 12-13.

100. Con la edición de los dos tomos de R. GIL Grimau, Aproximación a una bibliografía..., en prensa. 
$2005^{101}$. Hay que advertir que en las Actas del primer encuentro, de los 19 autores de comunicaciones, 11 eran árabes (7 de Marruecos, 2 de Egipto y uno respectivamente de Jordania y Líbano), junto con 8 europeos (6 españoles y 2 portugueses). Realmente, era una aplicación práctica de los deseos de política cultural de Alfonso de la Serna, "entre las dos orillas".

En realidad, creo que me identifico sobre todo con Rodolfo Gil en la aplicación académica y en las publicaciones (bibliografías, investigación y fomento de la investigación, divulgación) del estudio de los moriscos, a ambos lados del Estrecho, en la línea en la que nos alentó el embajador Alfonso de la Serna. Ha sido la línea de muchos otros encuentros y publicaciones que se iban haciendo en muchos sitios (especialmente en Oviedo, Teruel... y en Zaghouan y Túnez). Es lo que hemos hecho desde Alicante, identificándome yo también con la labor sobre los moriscos de España y sobre su exilio, de mis colegas los profesores María Jesús Rubiera Mata y Luis-Fernando Bernabé Pons: Congreso de Sant Carles de la Ràpita (Tarragona), en $1990^{102}$ (organizado con Luis F. Bernabé Pons) y Congresos de Alicante, en $1980^{103}$, en $1995^{104}$ y $2000^{105}$ (estos dos últimos dirigidos por María Jesús Rubiera, junto con su "Portal Digital" sobre Literatura de Mudéjares y Moriscos ${ }^{106}$ ), y la cooperación con los Simposios de

101. Véase las Actas ya publicadas del primero, en R. GIL GRIMAU, La política y los moriscos en la época de los Austrias. Actas del encuentro. Diciembre 1998. Sevilla La Nueva. Palacio de Baena, Sevilla La Nueva, 1999, 279 pp., con una presentación del director del encuentro R. GIL GRIMAU, “Introducción”, pp. 7-9, con 19 comunicaciones, entre ellas una del propio R. GIL GRIMAU, «La marginalidad de los moriscos, un fenómeno impuesto», pp. 175-181. En 2005, otro importante congreso, en el centenario de la $1^{\text {a }}$ edición del Quijote de Cervantes, un segundo congreso sobre Cervantes, el Quijote, lo moro, lo morisco y lo aljamiado, se celebró en Sevilla del 19 al 21 de mayo de 2005, organizado por la Sociedad Estatal de Conmemoraciones Culturales (SECC) y La Fundación Tres Culturas del Mediterráneo, en homenaje a la profesora e investigadora Dra. Soledad Carrasco Urgoiti, también dirigido por Rodolfo Gil. En esa misma línea de estudios sobre la relación de Cervantes con el mundo árabe mediterráneo, hay que señalar el libro editado por la catedrática de estudios árabes e islámicos M.J. RuBIERA MATA (ed.), Cervantes entre las dos orillas (Alicante, Universidad de Alicante. Vicerrectorado de Extensión Universitaria, 2006, 255 pp. ), con capítulos de temática diversa, por los profesores Rubiera, Bernabé Pons, El Erian, Epalza, Franco Sánchez y Stoll.

102. Véase M. DE EPALZA (dir. científico), L'expulsió dels moriscos. Conseqüències en el món islàmic i en el món cristià. Congrés Internacional. 380 è aniversari de l'expulsió dels moriscos. Sant Carles de la Ràpita 5-9 de desembre de 1990, Barcelona, 1994.

103. Del que saldría el libro de M. De Epalza (con M.J. Paternina y A. Couto), Moros y Moriscos en el Levante Peninsular (Sharq Al-Andalus). Introducción Bibliográfica., Alicante, 1983, y las secciones bibliográficas de la revista Sharq Al-Ándalus, luego con los futuros catedráticos de estudios árabes e islámicos Francisco Franco Sánchez y L.F. Bernabé Pons.

104. Véase M.J. Rubiera (coord.), «Coloquio "La Voz de Mudéjares y Moriscos" (Alicante, 29-31 noviembre 1995)», en Sharq Al-Andalus. Estudios Mudéjares y Moriscos, Teruel-Alicante, 12 (1995) [1996].

105. Véase M.J. Rubiera Mata (coord.), Carlos V, los moriscos y el Islam (Alicante, 20-24 noviembre 2000), Madrid, 2001.

106. Véase M.J. Rubiera MAtA (dir.), "Literatura de Mudéjares y Moriscos”, Edición digital de Biblioteca Virtual Miguel de Cervantes Saavedra (BIMICESA), Alicante, ed. Universidad, desde 2001. 
Mudejarismo de Teruel (también con Rubiera Mata, Bernabé Pons, Gafsi Slama y Bernard Vincent, entre otros) ${ }^{107}$.

Creo que se ha pasado en los años 70, todavía en la España franquista post-colonial, a la consideración política de los países árabes dividiéndolos en "Marruecos y luego todos los demás" y -después de la crisis petrolera de 1973"Marruecos, los países petrolíferos y todos los demás" al actual "Marruecos, los países árabes petrolíferos, sus dinastías monárquicas y todos los demás". Siempre estuvo Marruecos a la cabeza de las prioridades políticas españolas. Visión simplista, quizás, pero con un elemento de realidad indudable: la singularidad de Marruecos sobre los demás países árabe-islámicos, para la sociedad y la política españolas.

Viniendo diplomáticamente de su Embajada de Túnez a la de Rabat, Alfonso de la Serna acusó y encajó el golpe de esa singularidad marroquí, dentro del Magreb árabe. Y como eminente diplomático, lo estudió en profundidad y sacó sus conclusiones sobre las causas y sobre los remedios para solucionar los aspectos negativos de esas causas, que él resumía en "ignorancia mutua".

Por eso me ha interesado su pensamiento sobre ese tema, especialmente por los remedios a esa ignorancia, que interesan al universitario y escritor.

\section{El Mágreb ÁRABE ENCUAdRAdo EN OtROS PROBlemas DE VECINDAD DIPLOMÁTICA DE ESPAÑA}

Los dos últimos libros de Alfonso de la Serna, en una especie de catarsis, sitúan ya a Marruecos, al "problema hispano-marroquí", en unas visiones internacionales bastante globales: el de la visión estética de un europeo, pintor belga, ante la realidad marroquí con tintes hispánicos ${ }^{108}$, y el de la consideración de "fronteras sensibles de España" (Portugal; "el lejano Mágreb de ahí enfrente"; Francia; Inglaterra; América Hispana; Filipinas) ${ }^{109}$. El índice de este último libro, en la nota siguiente, indica algo de la perspectiva internacional del tema marroquí en Alfonso de la Serna, al tener que escoger para ese libro 26 de más

107. Véase participación de Rubiera y Epalza (y Bernabé Pons, desde 2004) en el Comité Científico de los Simposios de Mudejarismo de Teruel y con diversas ponencias y comunicaciones.

108. A. DE LA SERNA, en Tres visiones sobre Marruecos-España: La Guerra de África en la visión histórica de Galdós (por F. MÁrQuez VILLANUEVA), Marruecos y España en el espacio euro-Mediterráneo (por A. AzOUlay), Marruecos: color y esencia (por A. DE LA SERNA), y Apéndice: Discurso de Joaquín Costa en el meeting de la S.F.A.C., 1884, Sevilla, 2003, pp. 35-42. [Conferencia pronunciada en la inauguración de fotografías «Marruecos» de Harry Gruyaert. Madrid, marzo 2002, Fundación Carlos de Amberes.]

109. A. DE LA Serna, Las Fronteras Sensibles de España. Memoria fiel de nuestros vecinos históricos, Burgos, 2004, 189 pp. 
de un centenar de artículos suyos en "la página 3" del diario madrileño $A B C$, especialmente en lo referente al Magreb ${ }^{110}$.

Alfonso de la Serna concluye el primero de esos dos textos, con una reflexión humanista de las relaciones entre españoles y marroquíes ${ }^{111}$ :

"el asombro que a tantos viajeros a Marruecos ha producido el encuentro con lo que no es igual, con lo que es tan distinto. Pero a poco que intentemos penetrar más adentro, conocerle en su verdad -como lo ha intentado la lente humanizada de la cámara de Harry Gruyaert-iremos descubriendo al ser humano que habita allí, al sur de Tarifa, pero que también habita aquí, entre nosotros, emigrante del Mágreb extremo, que viene a la España extrema; entender, en fin, que al otro lado del Estrecho hay un viejo país, hecho de luces y sombras, de grandezas y de pobrezas, cuya alma ha tratado de ver un artista de Amberes, en Flandes, que sabe que, en fin de cuentas, el hombre sobre la tierra, cerca o lejos de cada uno de nosotros, siempre es igual: un hombre sobre la tierra".

\section{MARRUECOS: LOS MORISCOS Y ANDALUSÍES, OTRA VEZ COMO PUENTE}

En su último libro, Alfonso de la Serna sintetiza en un párrafo final la realidad agridulce de las relaciones hispano-marroquíes, con la esperanza de que el conocimiento de la historia hispano-árabe que nos une abra la esperanza a nuevos entendimientos. Entre muchas cosas bellas y reales que acaba diciendo de esa "frontera sensible de España", de ese "lejano Mágreb de ahí enfrente", reconoce finalmente el mucho trabajo que queda por hacer, al final de su libro de $2004^{112}$.

“Después, está Marruecos. También he vivido allí. Cualquiera que se ponga a pensar se dará cuenta de cuántos vacíos de la memoria, imágenes equívocas, recuerdos amargos, ideas contradictorias, ambiguos sentimientos de atracción y rechazo han sido dejados, como un poso confuso, en las mentes españolas, por conquistas y reconquistas, guerras y paces, convivencias y conflictos. Un valladar

110. Cap. 1, "Reencuentro con Portugal".

Cap. 2, "El lejano Mágreb de ahí enfrente.

Apartados: "Marruecos. La sombra del Islam. El lejano Mágreb de ahí enfrente. Cervantes en la Goleta. Bertuchi, pintor de Marruecos".

Cap. 3, "Caminos franceses a España".

Cap. 4, "Diálogos de las dos islas: Inglaterra y España".

Cap. 5. "América íntima".

Cap. 6. "Filipinas de los abuelos".

Cap. 7, "Fronteras sensibles". Apartado: "Tres fronteras sensibles".

111. A. DE LA SERNA, «Marruecos: color y esencia», p. 42.

112. A. DE LA SERnA, Las Fronteras Sensibles..., p. 183. 
psicológico, que no acaba de abatirse, dificulta a muchos españoles el reconocimiento de que, pese a todo lo que nos ha sucedido, a un lado y otro de esa frontera hay huellas imborrables y entrañables de un pasado común que de 'nuestro lado', cristalizó en el legado de los sabios y poetas de al-Andalus y en los tesoros de Córdoba, Granada o Sevilla".

Una vez expuestos los principales campos de actuación cultural de Alfonso de la Serna en el Magreb árabe, como diplomático y como escritor, en la promoción del conocimiento adecuado de la historia común, vamos a detenernos finalmente en su promoción del tema de los moriscos en Marruecos. Es tema al que él dio mucha importancia, en su acción en Túnez, con notable éxito. No tendrá menos éxito en Marruecos, aunque con un contexto político y cultural mucho más amplio y diferente, como se acaba de ver.

Para ir terminando, habría por tanto que mencionar una notable -y discreta- realización de Alfonso de la Serna en Marruecos. Por inspiración suya salió un número especial de la revista Academia. Revista de la Academia del Reino de Marruecos ${ }^{113}$, dedicado enteramente al tema "El éxodo de los moriscos hacia Marruecos". Tras la introducción del profesor e investigador de historia de AlÁndalus, miembro de la Academia, Dr. Muhámmad Bencherifa, diez historiadores especialistas marroquíes exponen diversos aspectos del tema (M. Bencherifa, A. Benmansur, A. Benabdallah [miembros de la Academia], M. Razuq, H. Buzinab, H. Al-Fakiki, A. Chahbar, I. Al-Uthmani, A. Al-Lauah, M. AbuTálib). Cuatro años después se publicaban las actas de un segundo encuentro sobre los moriscos, con otros 10 trabajos, de investigadores árabes, algunos que repetían (Bencherifa, Buzinab, 'Uthmânî) y otros nuevos (A. Busharb, M. Al-Hasnawî, M. Hayyî, M. Ibn-'Azzûz Hakim, M. Al-Qaddûrî, A. At-Tâzî, AlYarârî $)^{114}$. El tema del exilio morisco podía considerarse arraigado en los estudios históricos marroquíes modernos.

El embajador Alfonso de la Serna fue nombrado miembro numerario de la Academia del Reino de Marruecos, merecido reconocimiento a su labor como escritor sobre temas hispano-marroquíes y como promotor de los estudios hispano-árabes ${ }^{115}$.

113. Académia. Revue de l'Académie du Royaume du Maroc, «Numéro spécial consacré à l'exode des Morisques vers le Maroc» (Rabat), nº 15 (1997), 246 pp. [totalmente en lengua árabe].

114. Al-mûrîskiyyûn fî l-Magrib. An-nadwa ath-thâniya. Shifshawân [...] 1421 / 2000 ["Los moriscos en Marruecos. II Coloquio. Chauen/Chechaouen 2000 / 1421", editado totalmente en árabe por la revista de la Academia del Reino de Marruecos, Rabat, 2001].

115. En la página 5 del citado $n^{\circ} 15$ de la revista figura el listado de los miembros numerarios de la Academia, con el grupo naturalmente más numeroso de marroquíes (29), pero también con 40 miembros de otras nacionalidades: Arabia Saudí (4), Argelia (1), Austria (1), China (1), Egipto (1), Emiratos Árabes Unidos (1), Francia (7), India (1), Irak (1), Jordania (2), Libia (1), Mauritania (1), México (1), Palestina (1), Portugal (2), Reino Unido (1), Rusia (1), Senegal (2), Siria (1), Suiza (1), Túnez (1), Turquía (1), USA (4), Vaticano (1), y 1 español, Alfonso de la Serna, que compartió ese honor con el catedrático arabista y ex-embajador Emilio García Gómez, hasta el fallecimiento de éste, en 1995. 


\section{NOTA FINAL}

Mientras iba yo acumulando informaciones y reflexiones para las páginas de este trabajo iba pensando cuán superficialmente estaba valorando la acción cultural y la motivación plurifacética de Alfonso de la Serna, durante tantos años, en pro del conocimiento y de las relaciones hispano-árabes, habiendo algunas personas que los han seguido de cerca, en la sombra quizás, pero siempre presentes, confidentes privilegiados del propio embajador: su esposa Ana María Inciarte y sus hijos, Fernando, Blanca, Sol, Carmen, Ana y Paula de la Serna Inciarte, algunos de ellos con relación profesional directa con su misma profesión diplomática y cultural. A ellos quisiera dedicar mi modestísimo esfuerzo investigador por conocer, comprender y mostrar la acción del embajador de España, tal y como aparece en una serie de documentos y en mi propia memoria, tan limitada, selectiva y parcial. Ellos y los lectores sabrán comprender y perdonar que falten muchas cosas en esta exposición. 